\title{
Geological Oceanography of the Pliocene Warm Period: A Review with Predictions on the Future of Global Warming
}

\author{
Markes E. Johnson
}

Citation: Johnson, M.E. Geological Oceanography of the Pliocene Warm Period: A Review with Predictions on the Future of Global Warming. J. Mar. Sci. Eng. 2021, 9, 1210. https:// doi.org/10.3390/jmse9111210

Academic Editor: George Kontakiotis

Received: 11 October 2021

Accepted: 30 October 2021

Published: 2 November 2021

Publisher's Note: MDPI stays neutral with regard to jurisdictional claims in published maps and institutional affiliations.

Copyright: (C) 2021 by the author. Licensee MDPI, Basel, Switzerland. This article is an open access article distributed under the terms and conditions of the Creative Commons Attribution (CC BY) license (https:// creativecommons.org/licenses/by/ $4.0 /$ )
Department of Geosciences, Williams College, Williamstown, MA 01267, USA; mjohnson@williams.edu; Tel.: +1-413-597-2329

\begin{abstract}
Atmospheric carbon dioxide reached a record concentration of 419 parts per million in May $2021,50 \%$ higher than preindustrial levels at 280 parts per million. The rise of $\mathrm{CO}_{2}$ as a heat-trapping gas is the principal barometer tracking global warming attributed to a global average increase of $1.2{ }^{\circ} \mathrm{C}$ over the last 250 years. Ongoing global warming is expected to perturb extreme weather events such as tropical cyclones (hurricanes/typhoons), strengthened by elevated sea-surface temperatures. The melting of polar ice caps in Antarctica and Greenland also is expected to result in rising sea levels through the rest of this century. Various proxies for the estimate of long-term change in sea-surface temperatures (SSTs) are available through geological oceanography, which relies on the recovery of deep-sea cores for the study of sediments enriched in temperature-sensitive planktonic foraminifera and other algal residues. The Pliocene Warm Period occurred between $\sim 4.5$ and 3.0 million years ago, when sea level and average global temperatures were higher than today, and it is widely regarded as a predictive analog to the future impact of climate change. This work reviews some of the extensive literature on the geological oceanography of the Pliocene Warm Period together with a summary of land-based studies in paleotempestology focused on coastal boulder deposits (CBDs) and coastal outwash deposits (CODs) from the margin of the Pacific basin and parts of the North Atlantic basin. Ranging in age from the Pliocene through the Holocene, the values of such deposits serve as fixed geophysical markers, against which the micro-fossil record for the Pliocene Warm Period may be compared, as a registry of storm events from Pliocene and post-Pliocene times.
\end{abstract}

Keywords: El Niño-Southern Oscillation; coastal erosion; storm surge; paleotempestology

\section{Introduction}

The Iron Bridge across the Severn River in the West Midlands of England was the first of its kind, in 1779, to be erected anywhere in the world, and it is recognized as a World Heritage Site by the United Nations Educational, Scientific and Cultural Organization (UNESCO) [1]. Due to the local availability of iron ore, in addition to coal and limestone deposits necessary for the manufacture of iron, all the ingredients were present to launch the start of the industrial revolution in the British Isles. Other regions in other countries with those same natural resources were soon to follow. The atmospheric concentration of carbon dioxide fluctuated but did not rise above 280 parts per million prior to that era, based on the method of dry analysis of air inclusions preserved in ice cores recovered from deep within the glacial ice at the Vostok site in Antarctica [2]. Samples of ancient air, trapped in bubbles frozen in glacial ice at different levels within ice cores, track variations in $\mathrm{CO}_{2}$ concentrations over a span of 800,000 years, all at or below the level characterized by the pre-industrial age. In contrast, the Keeling Curve is based on analysis of air samples for resident $\mathrm{CO}_{2}$ measured at the Mauna Loa Observatory on the big island of Hawaii, initiated in 1958 and maintained to the present day by the National Oceanographic and Atmospheric Administration (NOAA). The upward slope of the plot deviates in a micro-rippled fashion based on the monthly mean of daily averages, but it reflects a steady rise overall in the concentration of atmospheric $\mathrm{CO}_{2}$ on a yearly basis. As such, the curve devised by the 
climate scientist Charles Keeling from the Scripps Institution of Oceanography has become the principal barometer tracking global climate change linked to a specific heat-trapping gas during the expanding industrial age [3]. In May 2021, the level of atmospheric $\mathrm{CO}_{2}$ measured on Mauna Loa peaked at 419 parts per million [4], the highest yet recorded, and with a value $50 \%$ higher than preindustrial levels. At this record level, it is calculated that humans are now adding roughly 40 billion metric tons of $\mathrm{CO}_{2}$ to the atmosphere each year [4].

Additional $\mathrm{CO}_{2}$ not only acts to increase the global average air temperate, but affects an increase in sea-surface temperatures (SSTs) registered around the globe, as the world's oceans absorb much of the excess heat. Measurement of ocean heat content is regarded as another way to quantify the rate of ongoing global warming. The years 2019, 2018, 2017, 2015, and 2016 rank as the five warmest years (in that order) for ocean heat values within the upper $2000 \mathrm{~m}$ [5]. Moreover, the ten years between 2010 and 2019 also rank as the top ten years on record [5]. Although variable on a seasonal basis in any given region, high SSTs provide the fuel to power tropical cyclones that originate in low latitudes but are capable of migrating as sea storms to much higher latitudes including boreal regions. Analysis of global data suggests that pools of warm surface water have formed more often and lasted longer during seasonal variations tracked since 1925 [6]. In turn, these data have led to the discovery that the exceedance probability of major tropical cyclones has increased over the last four decades [7]. Most big storms expire harmlessly in the open ocean, but a statistical review also indicates that ever stronger storms also have approached closer to land since 1982 [8].

Between 4.5 and 3.0 million years ago during the Pliocene Warm Period, the average global temperature is interpreted as $>2{ }^{\circ} \mathrm{C}$ higher than at present, and sea level stood no less than $16 \mathrm{~m}$ above today's datum $[9,10]$. During that interval, the pole-to-equator gradient in temperature was so flat that deposits near the Pliocene ice wedge in Canada's high Arctic on Ellesmere Island feature fossil camel bones and fossil tree remains dominated by a larch-forest habitat with mean annual temperature as much as $3.0^{\circ} \mathrm{C}$ above present [11]. Hence, the Pliocene Warm Period is regarded as a predictive analog to the future impact of ongoing global warming with the connotation raised as early as 1982 by M.I. Budyko in The Earth's Climate: Past and Future [12] and more explicitly in a seminal paper by Zubakov and Borzenkova in 1988 [13]. Much of the discussion regarding the Pliocene Warm Period revolves around the pattern of the El Niño Southern Oscillation (ENSO) in the equatorial zone of the Pacific Ocean, where semi-cyclical events that peak for a year or more result from the slowdown and stagnation of currents that move surface water from east to west and elevate warmer SSTs. These conditions not only spawn hurricanes off the southwest coast of Mexico and increase rainfall affecting the Pacific shores of North America, but also generate comparable storms and flooding farther afield called typhoons that reach landfall in countries across the western and northwest Pacific Ocean, including the shores of mainland China [14,15].

This work offers a review of literature on the geological oceanography of the Pliocene Warm Period, including techniques by which Pliocene sea temperatures are estimated from micro-fossils preserved in deep-sea cores. Opinions differ whether continual (permanent) El Niño conditions prevailed during the Pliocene Warm Period [16-18] or were more intermittent (dampened) during the same time interval [19,20]. A parallel approach to treatment of the Pliocene Warm Period, as well as the ensuing Pleistocene and Holocene time frames, relies on analysis of coastal storm deposits based on methods in paleotempestology. Such methods include evidence from storm-driven over-wash deposits in former marshes and beaches, oxygen-isotope anomalies recorded in speleothems, and tree-ring variations [21,22]. The evidence summarized in this review is focused foremost on coastal boulder deposits (CBDs) and coastal outwash deposits (CODs) from the margins of the Pacific basin and parts of the North Atlantic basin associated with heightened shore erosion and rainfall [23-30]. It is problematic to distinguish between genuine storm deposits and those caused by tsunami events [31,32]. Such difficulties are avoidable where 
paleo-deposits may be compared directly with deposits described in the aftermath of actual hurricanes, a research format pioneered by Ball et al. (1967) [33] with respect to Hurricane Donna that struck southern Florida in 1960 and by Paris et al. (2010) [34] with respect to the tsunami that struck the Indonesian island of Sumatra in 2004.

\section{Background Geological and Geographical Oceanography}

An authoritative summary by Miller et al. (2020) [10] covers long-term climate change in the Pacific basin during the Cenozoic, showing a marked shift from a warmer greenhouse world 65 million years ago to the fluctuating icehouse worlds of the Pleistocene during the last 2 million years. Smoothed curves for sea-surface temperature and sea level variations are adapted from this work (Figure 1) with alignments for the Early Eocene, Middle Miocene, and Pliocene climatic optima.

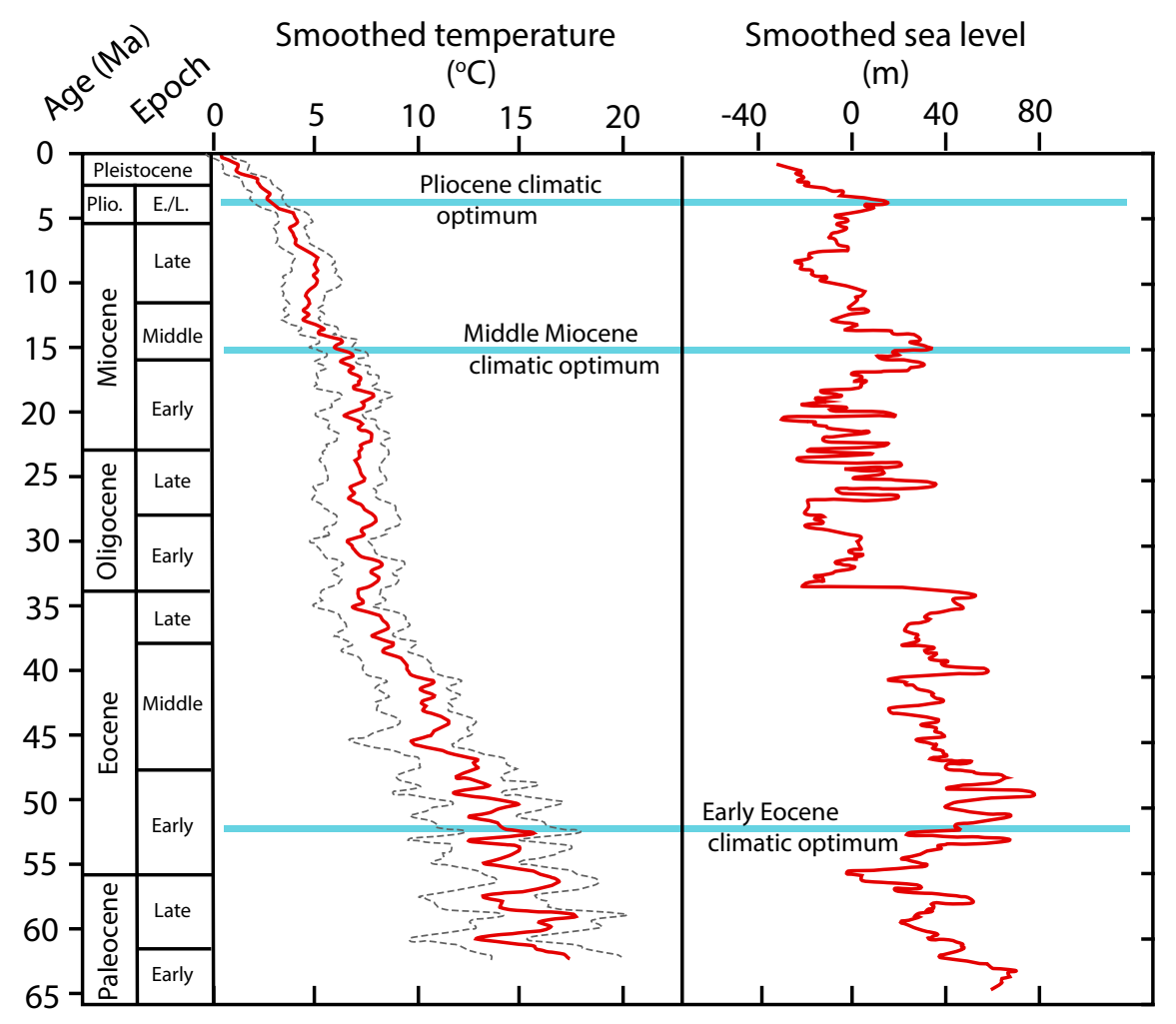

Figure 1. Geological history of sea-surface temperature and sea-level changes for the Pacific Ocean basin through the last 65 million years (modified from Miller et al., 2020) [9].

Compared to earlier intervals, the Pliocene Warm Period represents a diminishment in overall global temperature, from as much as $15^{\circ} \mathrm{C}$ warmer and with a sea level $75 \mathrm{~m}$ higher than today, during the ice-free Early Eocene climatic optimum (Figure 1). The suitability of the Pliocene Warm Period, as the closest analog to the effects of today's rapid change in global warming, is predicated on the similarity in global geography between the Pliocene world and today's world, as well as parallel external factors such as the intensity of sunlight falling on the Earth's surface [18]. The farther back in geologic time that climatic change is gauged, the more difficult it becomes to account for major differences in paleogeography and other possible external factors related, for example, to increased volcanic activity, extent of vegetative land cover, and other variations in topography compared to the present.

The basic mechanics of oceanic circulation and cyclonic storm development are summarized in the cartoon model for a generalized ocean with broad latitudinal extent, as found today in the Pacific and Atlantic oceans (Figure 2). The Inter Tropical Convergence Zone (ITCZ) is the irregular boundary along the Earth's equator where trade winds emanating from the northeast and the southeast converge, and where warm, moist air rises 
upwards into the atmosphere by convection. A pair of Hadley Cells are strongly formed astride the equator, where atmospheric low pressure dominates and moisture-laden air ascends between 10 to $15 \mathrm{~km}$ into the troposphere. Moisture is released as rain, after which upper-air currents convey dry air to latitudes centered around $30^{\circ}$ north and south of the equator. There, atmospheric high pressure brings the dry air back to the Earth's surface, some of which returns to the equator carried by the trade winds, and some is conveyed to higher latitudes to join westerly-directed winds located around $45^{\circ}$ north and south of the equator.

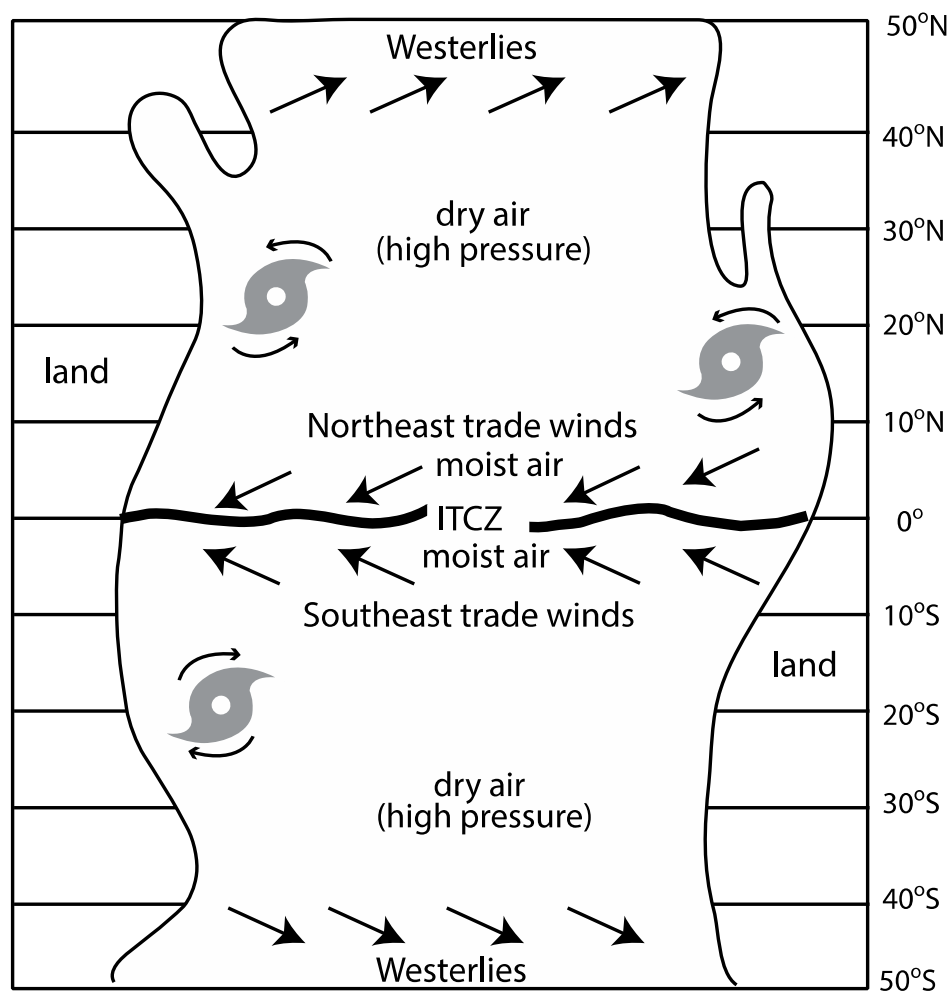

Figure 2. Cartoon model for present-day ocean-current circulation stimulated by the Westerlies and Trade winds with icons representing tropical cyclones (hurricanes/typhoons) that rotate counterclockwise in the northern hemisphere and clockwise in the southern hemisphere (ITCZ = Inter Tropical Convergence Zone). Marginal seas are figurative, but shown as coastal embayments characteristic of Mexico's Gulf of California and China's Yellow Sea.

Under localized climatic anomalies, where super-heated tropical air warms SSTs to or above $26.6^{\circ} \mathrm{C}$ through water depths reaching the upper $50 \mathrm{~m}$, the stage is set for the creation of a tropical depression leading to a tropical cyclone. As warm air rises above the sea surface, cooler air from surrounding areas swirls in to take its place, and the entire rotating mass undergoes further cooling with altitude leading to condensation and cloud formation. When wind speed within such a system reaches a minimum speed of $119 \mathrm{~km} / \mathrm{h}$, it is classified as a Category 1 hurricane. By definition on the Saffir-Simson scale, a Category 5 hurricane is initiated with wind speeds of $252 \mathrm{~km} / \mathrm{h}$. In the North Atlantic Ocean today, hurricanes tend to form at a latitude around $15^{\circ}$ north of the equator off the coast of Africa just south of the Cape Verde Islands. In the Northeast Pacific Ocean, hurricanes regularly form off the west coast of Mexico at the same latitude south of Acapulco. These disturbances may reach heights of $15,000 \mathrm{~m}$, but trade winds push the storms westward as discrete entities. Tropical cyclones rotate in a counter-clockwise direction in the northern hemisphere, whereas they rotate in the opposite clockwise direction in the southern hemisphere (Figure 2). It is strictly a matter of regional terminology, but these tropical storms are called hurricanes in the Atlantic and northeastern Pacific oceans. They are called typhoons in the central and northwestern Pacific Ocean. Due to the expanse of the Pacific Ocean 
along the equatorial zone, there exist other peculiarities ascribed to Walker circulation that affect cycles in the El Niño Southern Oscillation.

\section{Operational Definitions and Study Methods}

The unique environmental attributes of the Equatorial Pacific zone during normal years entail multiple temperature gradients both in zonal (latitudinal) and meridional (longitudinal) scale, as well as below the water surface and within the overlying atmosphere (Figure 3). Along the ITCZ where the trade winds converge, there typically exists a $5^{\circ} \mathrm{C}$ temperature difference between the sea surface in the warmer Western Equatorial Pool (WEP) and the cooler Eastern Equatorial Pool (EEP). The temperature gradient with depth below the WEP and EEP, or thermocline, is as much as four times as great in the west as it is in the east [17]. In addition, Walker circulation acts as a kind of zonal variation on the meridional Hadley Cell circulation, whereby warmer air in the west rises aloft and streams eastward above the equator where it descends to the EEP.

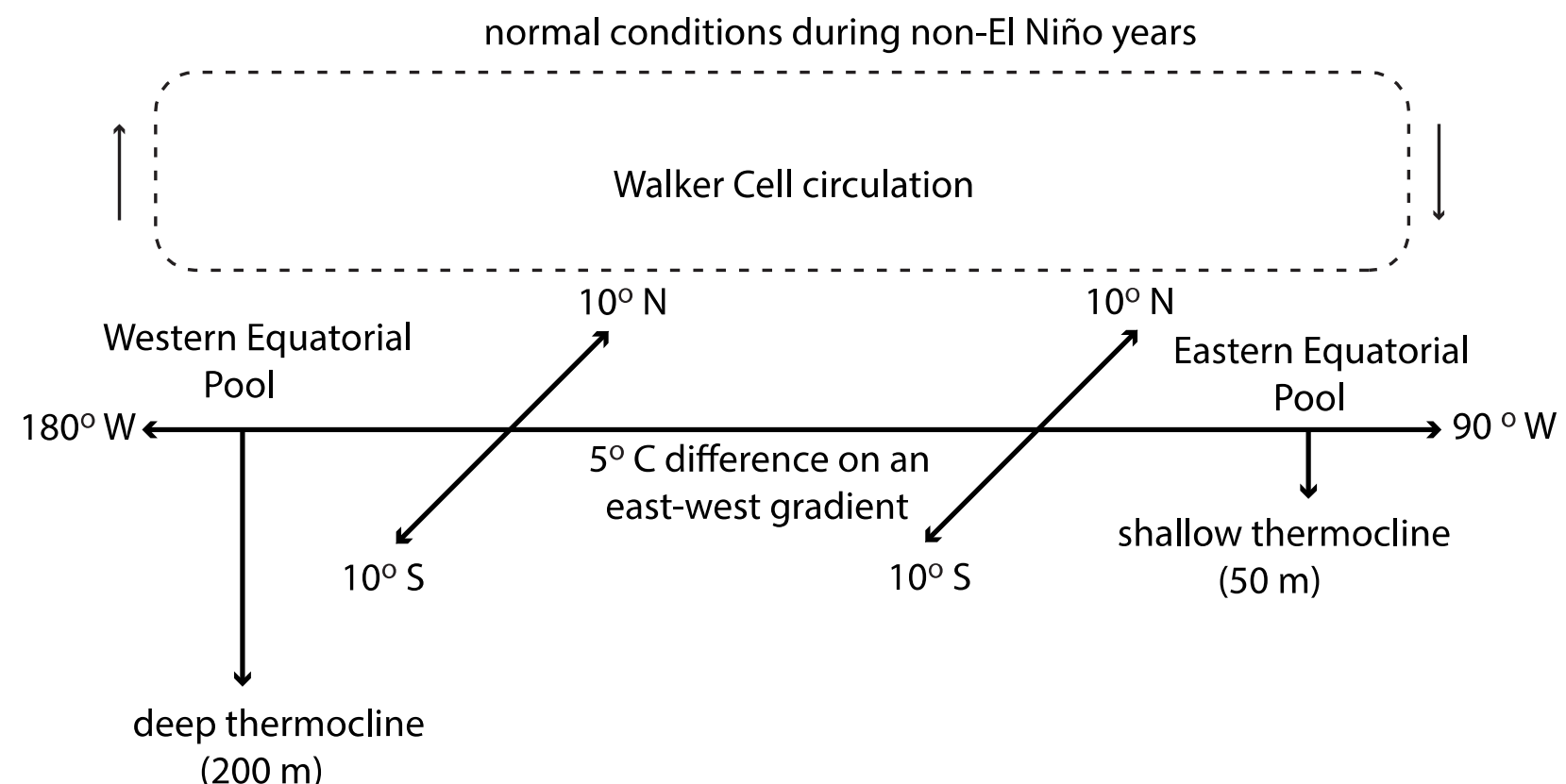

Figure 3. Sketch diagram showing the three-dimensional arrangement through the Equatorial Pacific Ocean zone under normal climatic conditions (non-El Niño years).

During El Niño years, this pattern breaks down where the cooler waters of the EEP are less insolated and more easily elevated in temperature due to the shallowness of the thermocline. Weakening of the south-flowing coastal California current and north-flowing Humboldt current that converge in the eastern Pacific deprive the EEP of a relatively cooler-water influx dependent on Ekman upwelling. As a result, the east-west asymmetry in temperature between the pools along the entire zone is ameliorated to the extent that it disappears [17]. Under these conditions, Walker circulation also dissipates. Hurricanes are more readily spawned off the coast of western Mexico, as well as typhoons in the mid-Pacific Ocean. Based on satellite surveillance over the past several decades, most of these storms are tracked to higher latitudes of the open ocean where they expire harmlessly. However, where landfall over ocean islands or against continental mainland occurs, the effects of coastal erosion due to storm waves and flooding due to attendant rainfall is devastating.

Direct observations of ENSO climate cycles underscore these variables along the Equatorial Pacific zone. For example, recurrent El Niño events were especially severe in 1972-1973, 1982-1983, and 1997-1998 [19], as well as more recently in 2014-2016. The technology involved in testing for ENSO conditions during past eras is complex and entails the 
sampling of temperature-sensitive foraminifera with a planktonic habit that accumulates after death as micro-fossils on the ocean floor. Retrieval of these samples is drawn from deep-ocean cores drilled into the ocean floor at hundreds of sites around the world. One of the more common methods is the application of a temperature proxy based on variations in $\delta^{18} \mathrm{O}$ derived from fossil foraminifera of various species [10]. Other proxy methods examine variations in $\mathrm{Mg} / \mathrm{Ca}$, also from fossil foraminifera such as Globigerinoides sacculifer [16]. Another proxy method targets alkenones produced by certain species of haptophyte algae equilibrated to a temperature proxy based on a $\mathrm{U}^{\mathrm{k}^{\prime} / 37}$ index $[35,36]$. Yet another index in use is the TetraEther index $\left(\mathrm{TEX}_{86}\right)$ found in integrated studies applying a combination of paleotemperature proxies [35]. The complexity in all this is exacerbated by the fact that different studies typically rely on a choice of different ocean cores drawn from a wide range in east-west spread but also a variable distance north or south of the equator. Moreover, expansion of studies into the Atlantic Ocean basin adds yet more complexity based on data derived from widespread ocean cores at higher latitudes in that region [37]. Finally, modeling studies expand on predictions based on some or all of the techniques cited above [19,38].

The effectiveness of warmer pools of ocean water in triggering major storms of hurricane/typhoon intensity during the Pliocene Warm Period in a positive feed-back loop [38] may be checked by examination of coastal boulder deposits (CBDs) that result from the impact major storms generating extreme wave energy. Likewise, coastal outwash deposits (CODs) signify the impact of rainfall and erosion during landfall of major storms. Regarding CBDs, various mathematical equations have evolved in complexity that allow for the measurement of eroded shore boulders to yield estimates of wave heights necessary for dislodgement from sea cliffs [39-41]. These may be applied to geological deposits of any age, but also to deposits in the direct aftermath of a modern storm as well as a modern tsunami in their shoreward impacts. For geological examples from the past, the challenge is to differentiate between the style of deposits due to sea storms and tsunamis [30,31].

\section{Results}

\subsection{Literature Review on the Pliocene Warm Period Based on Deep-Sea Cores}

Since the earliest suggestions on the potential of the Pliocene Warm Period as an analog to the future impact of climate change [12,13], a sizable amount of literature has followed, which remains both current and controversial [19]. Table 1 summarizes details from a sample of a dozen research reports published between 2005 and 2020. This review includes notations on the kind of study techniques applied, the number of locations around the world where primary research materials were collected, and a tally on opinions expressed as to the severity of the Pliocene Warm Period as an ENSO precursor. Studies are listed in Table 1 in order of appearance in the published literature [16-20,35,36,38,42-46]. Among the earliest such reports [16], the phrase "permanent El Niño" was introduced as a Pliocene phenomenon. The latest study consulted [20] argues against the "permanent El Niño" as rather a "dampened El Niño." To an outside reviewer, such terminology is needlessly extreme, and the substitution offered by Fedorov et al. (2010) [38] for a "continual El Niño" is adapted here, as is the counter appraisal for an "intermittent El Niño" (Table 1).

Several trends are evident in the growing sophistication of this research topic over a period of 15 years. The earliest study to advocate for a "permanent" Pliocene El Niño is based on data from only two ODP sites, separated by $90^{\circ}$ of longitude between the EEP and WEP [16]. A subsequent study increased the number of ODP sites to 85 [46] with inclusion of the Atlantic Ocean basin and an expansion in latitudinal range. Overall, the number of studies surveyed favors an interpretation of a continual El Niño state during the Pliocene against a slightly smaller number of skeptics. However, a significant number remained neutral, urging for additional studies. As debate among key participants intensified with time, later studies began to criticize the validity of techniques applied by earlier workers. The study by Tierney et al. (2019) [47] relies entirely on evidence derived from alkernones while rejecting, as flawed evidence, the $\mathrm{Ma} / \mathrm{Ca}$ ratios in planktonic foraminifera. Even so, 
that study concludes by admitting that a Pliocene atmospheric level of $\mathrm{CO}_{2}$ concentration higher than 400 ppm is likely to weaken Walker circulation in tandem with a meridional weakening of Hadley Cell circulation. The hard fact remains from land-based evidence, irrespective of data from deep-sea cores, that Pliocene temperatures in the high Arctic of Canada reached well above present-day conditions [11]. This kind of input suggests that other kinds of land-based evidence are relevant.

Table 1. Opinions on the Pliocene Warm Period and its severity as a precursor to future El Niño conditions. The abbreviation "alk" is for alkernones based on the $\mathrm{U}^{\mathrm{k}^{\prime} / 37}$ index. ODP refers to Ocean Drilling Program sites. A neutral opinion registered in this summary signifies a call for additional research.

\begin{tabular}{|c|c|c|c|c|c|c|}
\hline $\begin{array}{l}\text { Reference } \\
\text { List }\end{array}$ & Authors & Techniques Applied & $\begin{array}{l}\text { Number } \\
\text { ODP Sites }\end{array}$ & $\begin{array}{l}\text { Continual } \\
\text { El Niño }\end{array}$ & $\begin{array}{l}\text { Neutral } \\
\text { Opinion }\end{array}$ & $\begin{array}{l}\text { Intermittent } \\
\text { El Niño }\end{array}$ \\
\hline [16] & Wara et al. (2005) & $\delta^{18} \mathrm{O}, \mathrm{Mg} / \mathrm{Ca}$ & 2 & $x$ & & \\
\hline [17] & Ravelo et al. (2006) & $\delta^{18} \mathrm{O}, \mathrm{Mg} / \mathrm{Ca}$ & 4 & $x$ & & \\
\hline [42] & Dekens et al. (2007) & $\delta 18 \mathrm{O}$, alk. & 8 & & $x$ & \\
\hline [36] & Haywood et al. (2007) & $\delta 18 \mathrm{O}, \mathrm{Mg} / \mathrm{Ca}$ & 2 & & $x$ & \\
\hline [19] & Molnar \& Cane (2007) & modeling & other & & & $x$ \\
\hline [18] & Brierley et al. (2009) & $\mathrm{Mg} / \mathrm{Ca}$, alk. & 2 & $x$ & & \\
\hline [35] & Dowsett \& Robinson (2009) & $\mathrm{Mg} / \mathrm{Ca}$, alk. & 13 & & $x$ & \\
\hline [38] & Fedorov et al. (2010) & modeling & other & $x$ & & \\
\hline [43] & von der Heydt et al. (2011) & modling & other & & & $x$ \\
\hline [44] & O'Brien et al. (2014) & Mg/Ca, alk., TEX86 & 3 & $x$ & & \\
\hline [45] & Haywood et al. (2016) & $\delta 18 \mathrm{O}, \mathrm{Mg} / \mathrm{Ca}$, alk. & 85 & & $x$ & \\
\hline [46] & Tierney et al. (2019) & alk. & 28 & & & $x$ \\
\hline$[20]$ & White \& Ravelo (2020) & $\delta 18 \mathrm{O}, \mathrm{Mg} / \mathrm{Ca}$ & 1 & & & $\mathrm{x}$ \\
\hline Total & 13 & 5 & & 5 & 4 & 4 \\
\hline
\end{tabular}

\subsection{Review of Pliocene to Holocene Coastal Deposits in the Gulf of California}

In a summary of coastal boulder deposits from the Miocene and Pliocene, Ruban (2019) [48] examined 21 studies almost evenly divided between the two epochs and well distributed between the northern and southern hemispheres. All of these studies feature a mixture of boulder-size clasts exceeding $25.6 \mathrm{~cm}$ in diameter, although the original author's intent was not always explicit with identification of a CBD. Indeed, some are CODs attributed to a delta setting and some are tsunami deposits. Due to less time for erosion after deposition, the geological record for CBDs and CODs is potentially better when the search is widened to the last 2 million years of the Pleistocene and succeeding ten thousand years of the Holocene [49]. Deep geographic embayments (Figure 2), such as Mexico's Gulf of California, provide a fruitful place to search for and document storm-related CBDs and CODs. That the incidence rate of hurricanes reaching the Gulf of California decreased from an average return rate of 3.8 years between 1950 and 2000 to 1.3 years afterwards [50], confirms this region has become more vulnerable to hurricanes during the last decade. Table 2 summarizes storm deposits from the Pliocene [51-53], Pleistocene [27,54-56], and Holocene [23-26,57-59] preserved within the Gulf of California region.

The distance between the most northwesterly and southeasterly study localities, with documented storm deposits along the Gulf of California coastline, amounts to a spread of $900 \mathrm{~km}$ (Figure 3). All are well north of the Tropic of Cancer, far beyond the source of tropical cyclones that normally originate off the west coast of Mexico at a latitude of about $15^{\circ}$ north of the equator.

A complicating factor in the formation of CBDs is due to the density of the source rocks in sea cliffs subject to erosion by storms and tsunamis. The coastal geology within the Gulf of California is highly varied with examples of igneous rocks such as granite, andesite, and rhyolite, metamorphic rocks such as gneiss, and sedimentary rocks like limestone. Among these, the local granite was found to have a density of $2.52 \mathrm{~g} / \mathrm{cm}^{3}$ [27], which is denser than andesite, with levels measured between 2.26 and $2.34 \mathrm{~g} / \mathrm{cm}^{3}$ [26], which in 
turn is denser than rhyolite, with a sample density measured at $2.16 \mathrm{~g} / \mathrm{cm}^{3}$ [24]. In turn, all these igneous rocks are denser than the local limestone on Isla del Carmen, sampled with a density of $1.86 \mathrm{~cm} / \mathrm{cm}^{3}$ [23]. Essentially, a surface wave that shoals against the coast must work harder to extract a boulder of granite from its source than a slab of limestone of exactly the same size with lesser weight. Even so, some of the largest and heaviest rocks observed anywhere in CBDs from the Gulf of California are represented by enormous blocks of limestone with an estimated weight of nearly 6 metric tons [23].

Table 2. Pliocene to Holocene coastal boulder deposits (CBDs) and coastal outwash deposits (CODs) among islands and shores of Mexico's Gulf of California on the Baja California peninsula. Listing is north to south in each age category.

\begin{tabular}{|c|c|c|c|c|c|c|}
\hline $\begin{array}{l}\text { Reference } \\
\text { List }\end{array}$ & Authors & Age & Location & Class & Lithology & $\begin{array}{c}\text { Maximum } \\
\text { Boulder } \\
\text { Diam. }(\mathrm{cm})\end{array}$ \\
\hline [51] & Johnson et al. (2017) & Pliocene & Ballena Bay & COD & sandstone & - \\
\hline [52] & Johnson et al. (2016) & Pliocene & Isla del Carmen & COD & andesite & 64 \\
\hline [53] & Emhoff et al. (2012) & Pliocene & Isla Cerrolvo & COD & granite, gneiss & $\sim 35$ \\
\hline [54] & Johnson \& Ledesma- Vázquez (1999) & Pleistocene & Punta Antonio & CBD & granite, andes. & 32 \\
\hline [55] & Ledesma-Vázquez et al. (2007) & Pleistocene & Isla Coronado & overwash & sandstone & - \\
\hline [27] & Callahan et al. (2021) & Pleistocene & Isla San Diego & CBD & granite & 120 \\
\hline [56] & Tierney et al. (2012) & Pleistocene & Isla Cerrolvo & COD & granite, gneiss & $\sim 35$ \\
\hline [26] & Guardado-France et al. (2020) & Holocene & Isla San Luis & CBD & andesite & 80 \\
\hline [57] & Kozlowski et al. (2018) & Holocene & Volcán Prieto & CBD & basalt & $\sim 35$ \\
\hline [58] & Johnson et al. (2012) & Holocene & Angel Guarda & CBD & andesite & $\sim 35$ \\
\hline [24] & Johnson et al. (2019) & Holocene & Almeja Bay & CBD & rhyolite & 268 \\
\hline [23] & Johnson et al. (2018) & Holocene & Isla del Carmen & CBD & limestone & 182 \\
\hline [25] & Johnson et al. (2020) & Holocene & Escondido Port & CBD & andesite & 131 \\
\hline [59] & Backus et al. (2012) & Holocene & Isla Cerrolvo & COD & granite, gneiss & $\sim 35$ \\
\hline Total & 14 studies & 0 to $4.5 \mathrm{my}$ & 900-km spread & & mixed & \\
\hline
\end{tabular}

Storm deposits of Pliocene age within the Gulf of California are represented by CODs of unusual thickness [51-53]. Crude layering within CODs provides some insight regarding the repetition and overall span of time during which such deposits continued to be formed at the same locality. Among the examples from Table 2, the most intriguing is the $60-\mathrm{m}$ thick Tiombó conglomerate, representing a mega-delta complex on the east coast of Isla del Carmen [52]. Boulders within the conglomerate are exclusively andesite in composition (Figure 4), the largest of which has a maximum diameter of $64 \mathrm{~cm}$. For the most part, these clasts are well rounded as a consequence of travel to the coast under flood conditions from a source high in the peninsular mountains as much as $35 \mathrm{~km}$ to the west.

The actual thickness of the complex is unknown, because contact between the base of the conglomerate and underlying andesite in the Miocene Comondú Group is below present sea level and most likely buried in the subsurface. However, scarce fossil pecten shells from the lowest part of the exposed deposit confirm a Pliocene age. Raised marine terraces, on the margins of the complex correlated with the middle and youngest parts of the Pleistocene, suggest that the uplifted complex spans the Pliocene and may include material from the oldest part of the Pleistocene [23]. In cross-section, the Tiombó conglomerate traces an arch that extends for $2 \mathrm{~km}$ (Figure 5), with thick layers that form an arch (Figure 6) tilt seaward $5^{\circ}$ and thin to a wedge shape in the landward direction. This configuration conforms to a massive delta complex that remained active through much of the Pliocene with distinct pulses of conglomerate fed to the delta front from highlands before Isla del Carmen was tectonically severed from the peninsular mainland. 


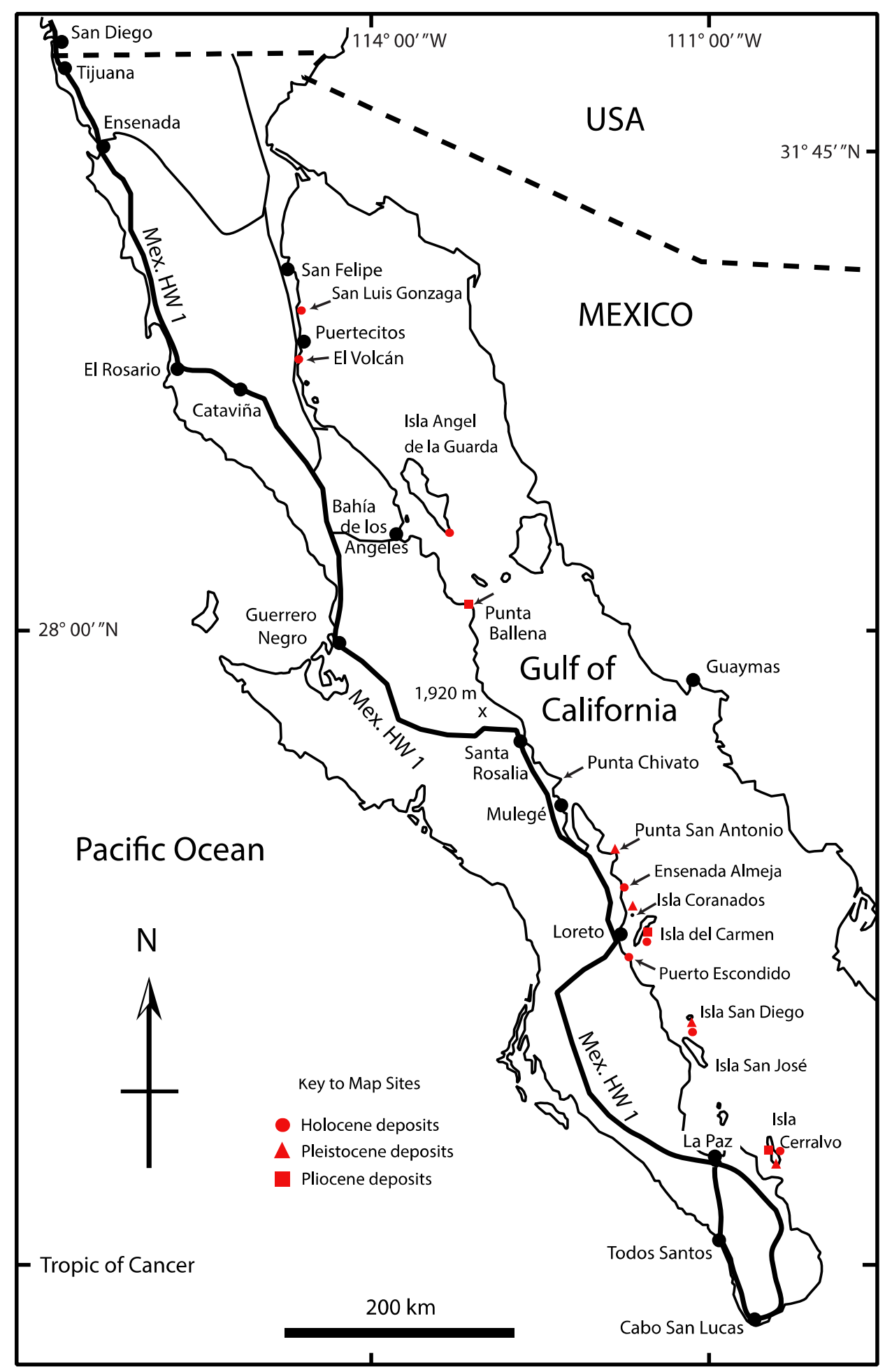

Figure 4. Mexico's Baja California and adjacent Gulf of California showing 14 localities with storm deposits of varying ages: Pliocene (square), Pleistocene (triangle), and Holocene (circle). See Table 2 for details. 


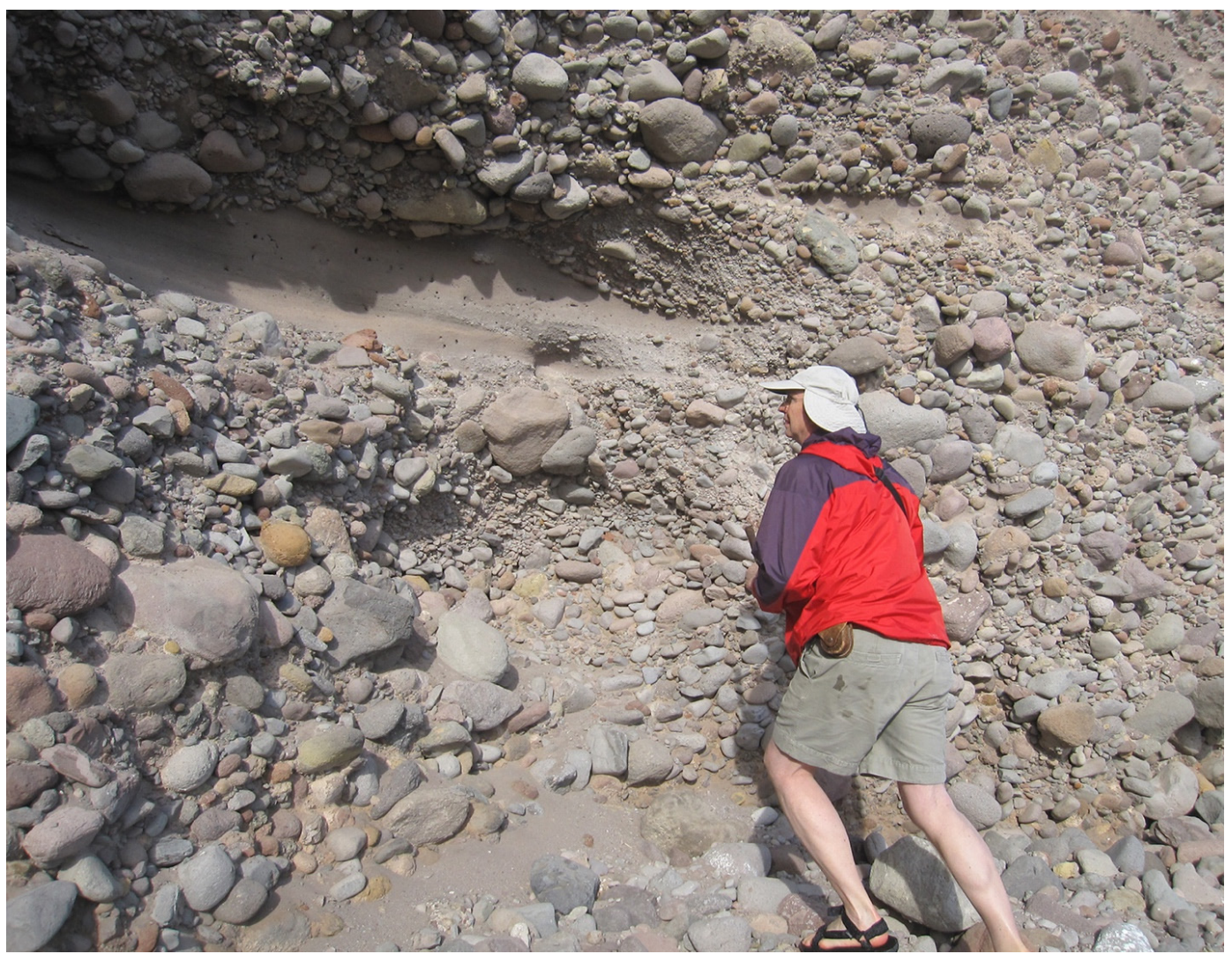

Figure 5. Exposed lower part of the Pliocene Tiombó conglomerate on the east coast of Isla del Carmen, showing typical composition of well-rounded andesite boulders parted by sandstone seams. Each of several packages offset by such seams represents a major rainfall event that carried coarse material through stream beds to the coast.

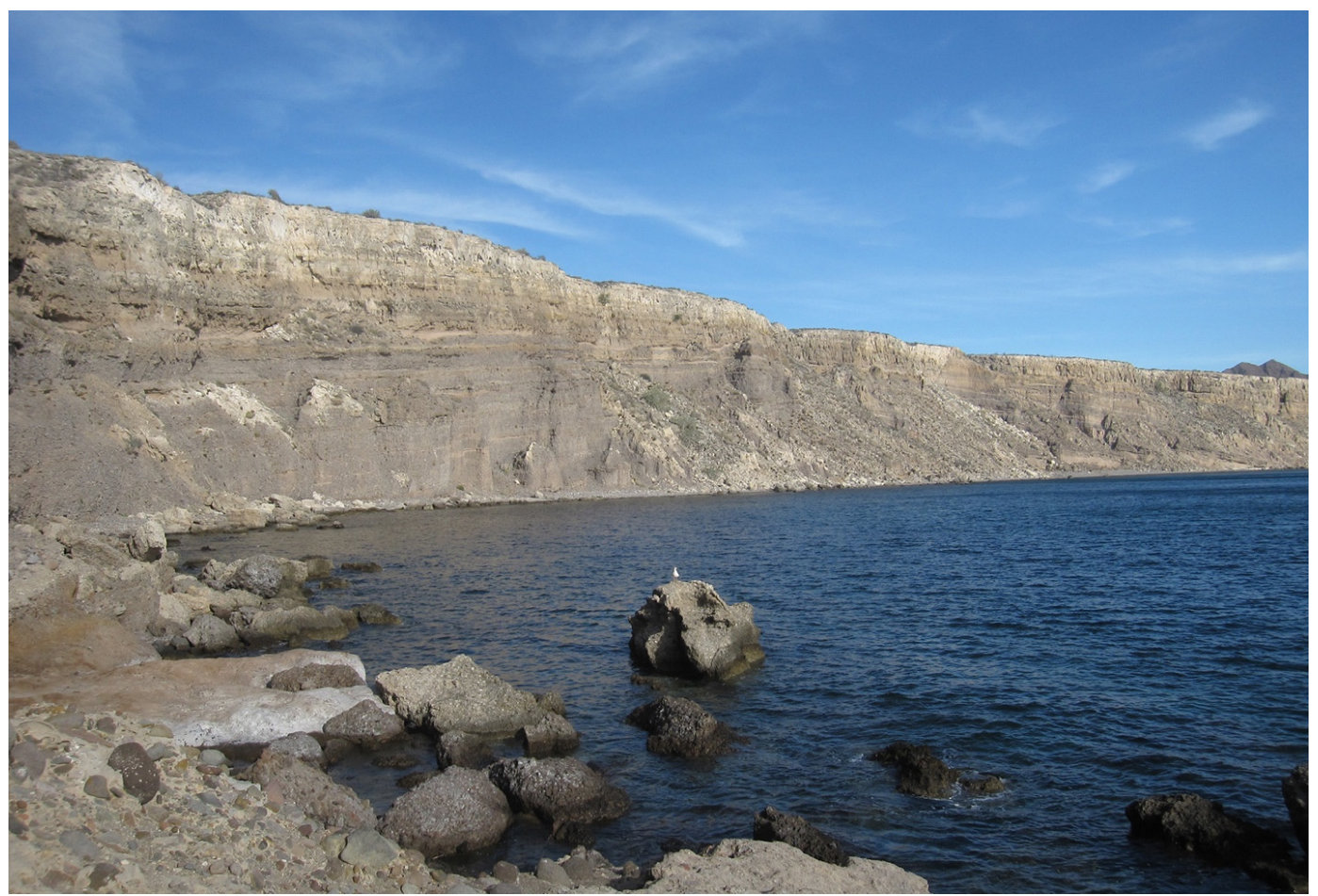

Figure 6. Oblique view of the arch-shaped PlioceneTiombó conglomerate in cross-section, stretching south to north over a distance of $2 \mathrm{~km}$ on the east coast of Isla del Carmen. 
Another Pliocene deposit, also linked with outwash dynamics dependent on stormrelated rainfall, occurs far to the north of Isla del Carmen (Figure 4), where the 50-m thick Ballena fan delta covers a map area of $4 \mathrm{~km}^{2}$ with sandstone layers dipping nearly $3^{\circ}$ seaward in an arcuate pattern [51]. Equally far to the south of Isla del Carmen, yet another Pliocene deposit, with carbonate sands framed above and below by thick boulder deposits, occurs at Paredones Blancos on Isla Cerravo (Figure 4) [52]. In this case, coarse outwash deposits stripped from the interior of a large island are interrupted by an interval of subsidence and relative rise in sea level that filled a $0.5-\mathrm{km}$ wide embayment.

Upper Pleistocene deposits, correlated with Marine Isotope Substage 5e during the last interglacial episode roughly 125,000 years ago, also are well represented in the Gulf of California (Table 2), although not nearly at the same scale as older Pliocene storm deposits. Rhodolith sand deposited in a paleolagoon on Isla Coronados (Figure 7) are interpreted as repetitive overwash events during major storms arriving from the south that topped a barrier formed by solid andesite basement rocks [55].

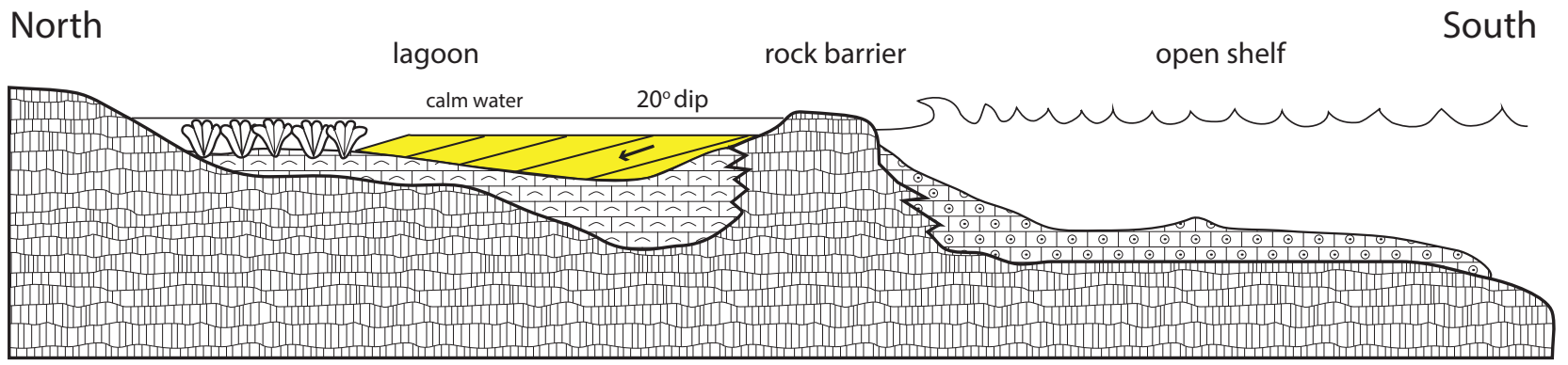

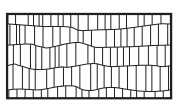

Andesite

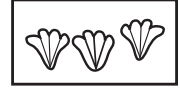

Coral reef

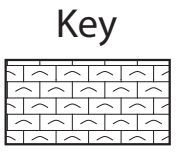

Bioclastic limestone
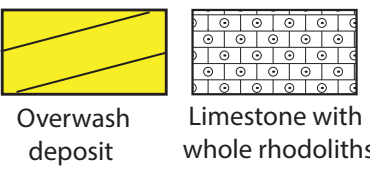

Figure 7. Cross-section through a Late Pleistocene lagoon uplifted on the south shore of Isla Coronados, showing an overwash deposit with multiple layers representing individual storm events that arrived from the south and left a succession of tilted beds off-lapped to the north [55].

The tilted beds within the lagoon amount to $6.5 \mathrm{~m}$ of vertical fill, but they are organized as individual beds from 40 to $60 \mathrm{~cm}$ in thickness dipping $20^{\circ}$ to the north off the top of the barrier [53]. Each bed is interpreted as a separate storm event that required sufficient energy to carry carbonate sand up and over a rigid barrier from the sea floor to the south. Three other Upper Pleistocene deposits are noteworthy, located north of Isla Coronados at Punta San Antonio and farther south on Isla San Diego and Isla Cerralvo in the lower Gulf of California (Table 2). The Punta San Antonio locality features a meter-thick CBD formed by a mix of eroded granite and andesite boulders that became colonized by a distinctive intertidal biota of bivalves and encrusting red algae [54]. The deposit on Isla San Diego features a stack of crudely imbricated granite boulders that incorporate eroded coral colonies dislodged by storm waves striking the island's east shore [27]. On Isla Cerralvo, thin cobble/boulder beds buried a succession of five coral colonies that grew in place through a vertical thickness of $3 \mathrm{~m}$, with each cycle initiated by a storm event that washed conglomeratic debris from the island's interior to the shore [56].

Several examples of Holocene storm beds are described from the Gulf of California, most of which are modified CBDs that form distinctive bars connected to and eroded from rocky shores under episodic storm attack. The composition and size of boulders incorporated within these deposits vary considerably (Table 2). The boulder deposit at Almeja Bay (Figure 8) is noteworthy for various reasons [24], among which is that it includes some of the largest eroded boulders on record in the gulf region. Coastal erosion contributing to bar development is implied to be ongoing at this site. Table 2 lists an 
individual rhyolite boulder with a diameter of $268 \mathrm{~cm}$ at this locality, estimated to weigh 4.3 metric tons and requiring wave shock from a 16-m high wave to dislocate it from nearby cliffs [24]. Such a huge boulder is an outlier, but an eye-witness account with storm waves filmed from the last major hurricane to strike the area in 2014 offers evidence of wave heights easily reaching $8 \mathrm{~m} \mathrm{[24].} \mathrm{This} \mathrm{level} \mathrm{of} \mathrm{storm} \mathrm{activity} \mathrm{would} \mathrm{be} \mathrm{sufficient} \mathrm{to} \mathrm{shift}$ most of the lesser boulders in the unconsolidated deposit.

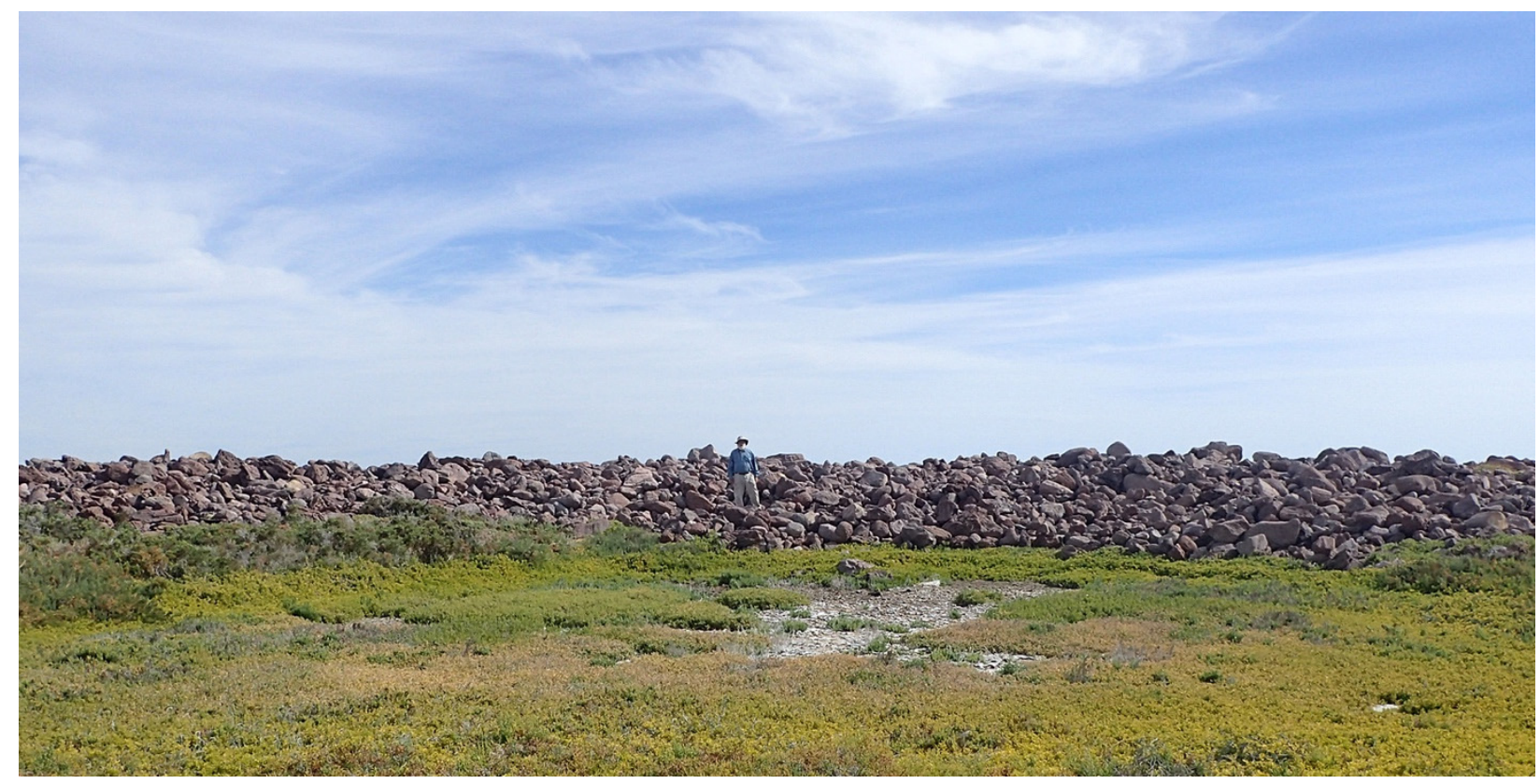

Figure 8. Inner side of an unconsolidated Holocene deposit at Ensenada Almeja formed by rhyolite boulders eroded from an adjacent sea cliff (out of view to the right) stacked to a height of $2 \mathrm{~m}$ [24].

On Isla Cerralvo in the lower Gulf of California (Figure 4), Backus et al. (2012) [59] documented 39 fan deltas around the island's circumference that represent CODs formed by granite and gneiss debris washed through a network of radial drainage channels from the interior. What is most intriguing about this mid-size island, $136,000 \mathrm{~km}^{2}$ in area, is its vulnerability to hurricanes, several of which made direct hits in recent years, including Lorena in 2019, John in 2006, Ignacio in 2003, and Marty also in 2003. Although maximum boulder size is small, around $35 \mathrm{~cm}$ in diameter (Table 2), the island provides a good model for the dynamic development of storm-related CODs in the past.

\subsection{Review of Pliocene to Holocene Coastal Deposits in the North Atlantic Basin}

Storm deposits attributed specifically to the Pliocene Warm Period are rare, but an unusual example from Lower Pliocene strata at Mallbusca on Santa Maria Island in the Azores is well documented [60]. Santa Maria is the only island among the archipelago's nine islands with a stratigraphic record spanning the Pliocene and parts of the Pleistocene, complete with abundant fossils. The storm sequence (Figure 9) consists of a continuous 5-m thick package distinguished by laminae composed of heavier, dark minerals dominated by pyroxene, olivine and plagioclase, alternating with lighter carbonate grains draped over a disconformity surface represented by a low rocky shore, distinguished by an intertidal to shallow-water biota including encrusting bivalves and coralline red algae. The top part of the storm bed is penetrated by a variety of trace fossils that burrowed from above as much as a meter into the sands from sometime after the storm ended. The interval in between is entirely barren of fossils. 


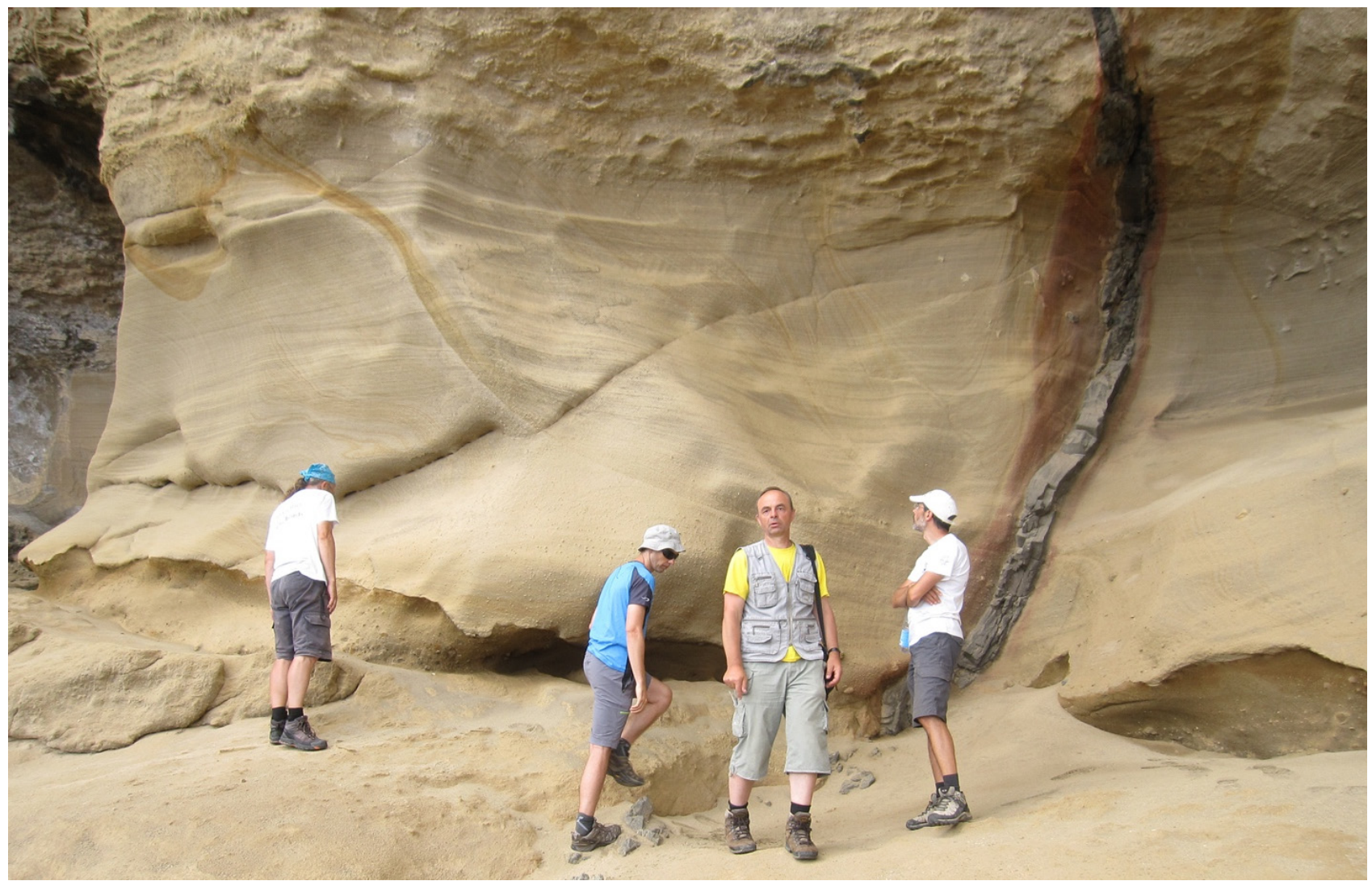

Figure 9. Storm deposit from the Lower Pliocene represented by a singular 5-m thick sandstone body that washed over a low-relief rocky shore at Malbusca on the south coast of Santa Maria Island in the Azores [60].

The Pliocene sand body may be traced laterally over a distance of $750 \mathrm{~m}$ before termination against the flanks of a lava delta. The deposit is largely two-dimensional, but the size of the open bench on which it sits allows for a conservative estimate of volume at $14,500 \mathrm{~m}^{3}$ interpreted to have been transported onshore from an adjacent sandbar during passage of a major hurricane [60].

Upper Pleistocene (Marine Isotope Substage 5e) and contemporary CBDs from Santa Maria Island also have been studied for CBDs [28] compatible with the methodology undertaken with regard to Mexico's Gulf of California [23-27]. In particular, the southeastern corner of the island at Punta do Castelo exhibits a matching set of Pleistocene and Holocene conglomerates with individual boulders that register a maximum half-meter in diameter. According to the mathematical models of Nott (2003) [39], these are estimated to have formed under wave heights between 5.3 and $5.5 \mathrm{~m}$. The mathematical equation applied by Pepe et al. (2018) [41] yields a more exaggerated result for the same units. Passage of modern-day tropical cyclones in this area is not unusual, and full-fledged hurricanes have struck the Azores most recently in 1998, 2006, and 2012, when wave heights of $5.5 \mathrm{~m}$ or more would be expected against island shores.

A similar study was performed on boulder slumps from the Upper Pleistocene (Marine Isotope Substage 5e) at El Confital beach on Gran Canaria in the Canary Islands [29], which like the CBDs in the Azores are derived from basalt. Basalt has a higher rock density than granite, and the rock density of basalt from El Confital beach was determined to yield an average value of $2.84 \mathrm{~g} / \mathrm{cm}^{3}$. Six trials based on samples between 24 and 30 basalt boulders each yielded average estimates of wave heights between 3.9 and $4.8 \mathrm{~m}$ based on the equations of Nott (2003) [39]. Here, the mathematics from Pepe et al. (2018) [41] makes a reasonable match. Moreover, the study from El Confital also lists 26 major storms impacting Gran Canaria since 1713. Few such records provide eye-witness details on 
observed wave heights, but a major storm in 1966 involved wave heights between 10 and $12 \mathrm{~m}$ at the coast, and another storm in 1968 was reported to entail wave heights of $8 \mathrm{~m}$ [28]. Wave heights within that range during the late Pleistocene would have been adequate to dislodge the largest boulders at El Confital.

Elsewhere in the North Atlantic basin, huge limestone boulders stranded above the island shores of Bermuda and the Bahamas [61,62] have attracted much the same interest in storm waves during the Late Pleistocene as a possible warning about future superstorms related to global warming. Likewise, tropical cyclones that form hurricanes are not expected to migrate to high latitudes in boreal settings, but during the last decade at least four storms of hurricane intensity struck Norway's Arctic coast [30], and Holocene CBDs along that coast are of interest. The boulder beach at Støypet on Leka Island formed after glacial retreat around 10,000 years ago and is composed of unconsolidated cobbles and boulders eroded from sea cliffs exposing low-grade chromite ore with a rock density of $3.32 \mathrm{~g} / \mathrm{cm}^{3}$. This is the highest-density rock type yet studied for its hydrological properties in a coastal setting, and the results based on the predictive equations of Nott (2003) and Pepe et al. $(2018)[39,41]$ are compatible in suggesting that shore erosion from wave heights between 5 and $7.5 \mathrm{~m}$ was possible.

\section{Discussion}

Studies predicting future superstorms based on CBDs from the geologic past elicit controversy related to: (1) challenges to the efficacy of mathematical equations to estimate wave heights and flow regimes based on boulder size and rock density, (2) alternate sources other than sea storms and attendant rainfall that explain similar deposits, and (3) past geographic configurations different from today's world as an influence on climate unrelated to global warming.

\subsection{On the Efficacy of Mathematical Equations}

Hydrodynamic equations following the approach pioneered by Nott (2003) [39] with subsequent iterations $[40,41]$ are criticized on the basis of clifftop boulders along the Atlantic coasts of Ireland and Scotland [63], which have a storied record of study by different investigative teams [64-66]. The claim is made that such equations are flawed and should be abandoned because they yield unrealistic estimates. These concerns appear to be valid due the enormous size of limestone blocks quarried from clifftops during extreme wave events [63]. Clifftop and other boulder deposits from the Reykjanes Peninsula of Iceland [67] partly demonstrate the over performance of computational estimates in contrast to known wave heights during that region's Atlantic storms that regularly reach $15 \mathrm{~m}$ or more. Among 46 study sites from 10 different areas on the Reykjanes Peninsula, more than half the formulaic wave heights calculated for basalt boulders fall above the bench mark of $15 \mathrm{~m}$. Twenty percent of the formulaic calculations predict wave heights of $25 \mathrm{~m}$ or more. The Selatangar site from this study [67] was the additional single palaeo-deposit to yield a wave-height estimate of $14 \mathrm{~m}$ in agreement with observations on contemporary storms.

In the Pacific Ocean basin, Super Typhoon Haiyan passed over the Philippine islands in November of 2013 as a Category 5 storm packing top wind speeds of $315 \mathrm{~km} / \mathrm{h}$ with devastating consequences as one of the most powerful storms to make landfall yet recorded [68]. Studies on the volume and density of blocks dislodged from low-lying limestone cliffs on the Calicoan island in the path of the typhoon $[69,70]$ reached the same conclusion that formulaic predictions [39-41] on wave height for large blocks far exceed the maximum wave height of $18.7 \mathrm{~m}$ that occurred offshore the study area [71]. The dynamics of clifftop erosion may be peculiar in this regard, involving differences between compressive hydraulic pressure due to head-on wave impact against seams and joints in a layered rock face and tensile stress on the underside of lip overhangs [72]. It is not clear that caution against use of the equations inspired by Nott (2003) [38-40] is justified when dealing with rocky shores other than limestone, whether layered or not. In any case, those formulae remain the only predictive tool available for application to CBDs from the geologic past, 
including those much older than the Pliocene. An approach certain to be useful in future studies of modern CBDs of all types is one that tags boulders with identification markers so they may be tracked for movement following the next major storm event having verifiable wave heights. With data on hand regarding a range in boulder size and density from different rock types susceptible to movement, it should be possible to make comparisons with boulder conglomerates that formed in the distant past.

\subsection{On Mistaken or Inconclusive Classifications}

Earthquakes that rupture the seabed and/or trigger the collapse of volcanic island flanks are the source of tsunamis that impact coastal zones and may result in CBDs similar to those caused by sea storms. Regarding studies in the Philippines conducted soon after Super Typhoon Haiyan $[69,70]$, the CBD consisting of limestone blocks peeled off coastal cliffs is shown, by the timing of the study, to be clearly storm induced. Likewise, the study of coastal deposits at Banda Aceh on Sumatra in Indonesia [34] is indisputable as to its source due to a major tsunami in 2004. In some regions, such as the Canary Islands in the North Atlantic, CBDs may originate from sea storms, as argued for the Pleistocene boulder slumps at El Confital beach on Gran Canaria [29], or from a Pleistocene tsunami related to volcanic flank collapse on the same island [73]. The sedimentology of the two deposits is entirely different, although involving a wide range of boulder sizes. At El Confital, the deposit is formed by well-rounded boulders limited in vertical thickness and located adjacent to the present shore, whereas the inland deposit from the Agaete valley on the same island occurs between 41 and $188 \mathrm{~m}$ above sea level, and is dominated by angular volcanic clasts that decrease in size with altitude intermixed with soil and colluvium as well as broken marine shells.

Deposits on volcanic islands elsewhere in the northeast Atlantic fit the same profile of poorly sorted materials, including huge basalt blocks and mixed soil found at elevations high above present sea level, among them the megatsunami deposit on Santiago Island in the Cape Verde archipelago studied by Ramalho et al. (2015) [74]. The deposits feature enormous boulders up to $8 \mathrm{~m}$ in diameter and point to wave run-up heights exceeding $270 \mathrm{~m}$ above sea level. In this example, the tsunami appears to have been triggered by a volcanic flank collapse on the adjacent island of Fogo about 73,000 years ago. Authors studying the clifftop boulders in western Ireland $[63,65]$ are adamant that the possibility for an origin due to offshore tsunami events at that latitude is mistaken. At the same time, others studying CBDs in the Mediterranean region, such as the Pleistocene and Holocene boulders on Malta [75] favor extreme storm events but are unable to rule out rare tsunami events also known to have occurred in that region.

Controversy likewise surrounds the 10-m thick Pliocene deposit at Caleta Hornitos in northern Chile, which includes boulders, large rock slabs, and breccia laterally traceable for nearly $2 \mathrm{~km}$, first linked to a possible tsunami event [76] but reclassified as a massive debris flow triggered by an earthquake in the Andean subduction zone of coastal Chile [77]. The example is intriguing, because the tsunami connection is tied to the Eltanin impact site in the Drake Passage off the southwestern tip of South America, which represents a different non-climate related source of disruption capable of producing a significant CBD. However, the two events are correlated with different time horizons, although both within the Pliocene [77].

\subsection{On the Bearing of Subtle Geographic Differences}

As early proponents for a permanent Pliocene El Niño, Wara et al. (2005) [16] argued that the similar configuration of Pliocene continents and oceans placed few constraints on comparisons with today's world and the forecast of future global warming. Although subtle in scale, the open passage between North America and South America, prior to final closure by the Isthmus of Panama 3.5 million years ago [78], overlaps with the Pliocene Warm Period. A global paleogeographic reconstruction for the Pliocene Period (Figure 10) marks the location several Pliocene study sites covered in this review, and illustrates the 
ramifications with respect to atmospheric and oceanic circulation attendant on such and open passageway.

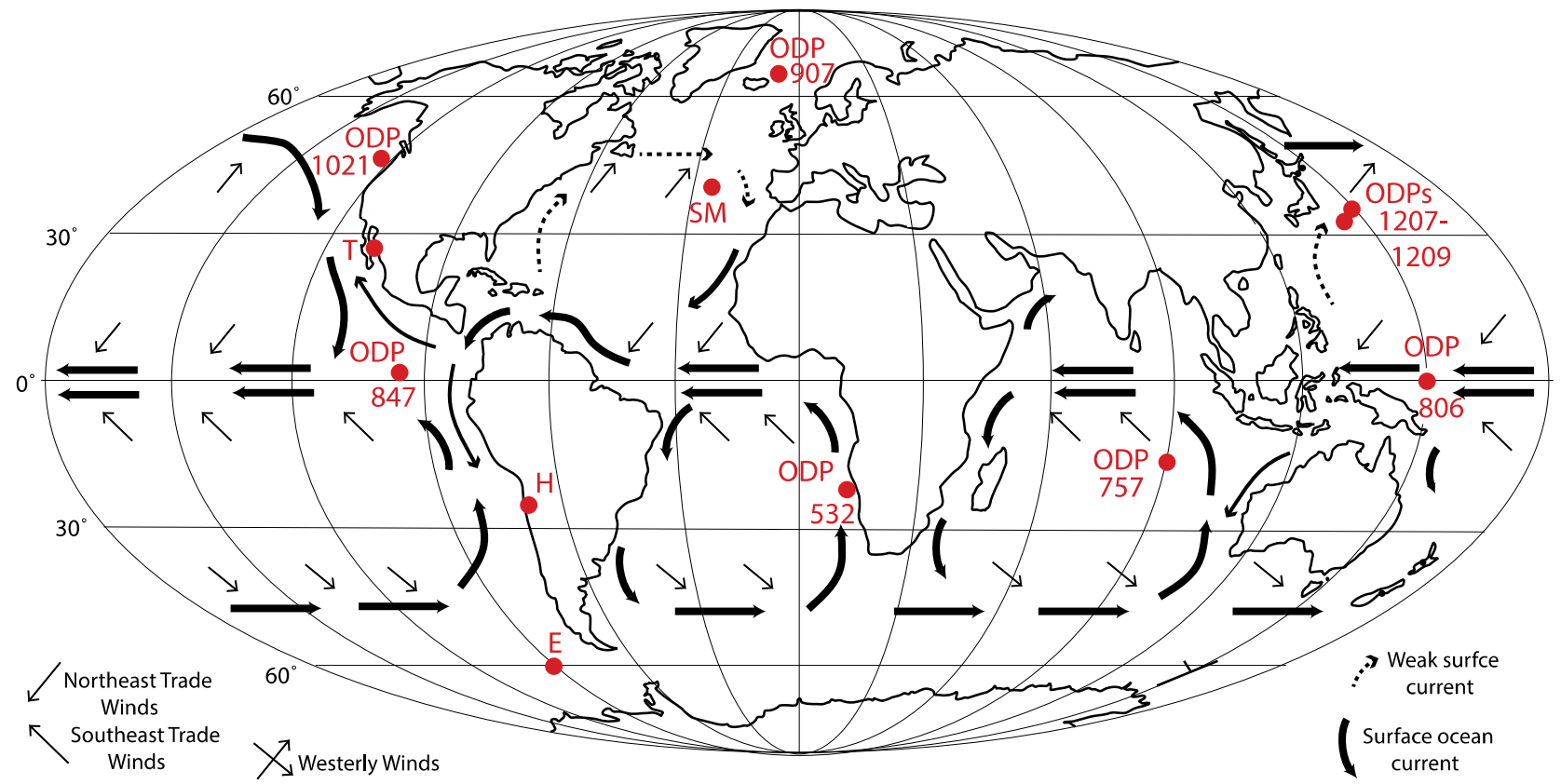

Figure 10. Global geography for the Pliocene Period, showing projected atmospheric circulation and ocean currents as well as the locations of many key study sites referenced in this review. Weakened surface currents shown by a dashed line. Map abbreviations: SM = Santa Marina Island (Azores archipelago), T = Tiombó conglomerate (Gulf of California), ODP = Ocean Drilling Project sites, $\mathrm{H}=$ Caletas Hornitos (northern Chile), and E = Eltanin impact site (off the southern tip of South America).

A small but significant difference is that a through-going ocean current was able to flow westward between the continents from the Atlantic Ocean into the Pacific Ocean. As consequence, the Gulf Current in the North Atlantic was almost certainly weaker compared to today [43]. Among studies probing evidence on the status of El Niño cycles during the Pliocene Warm Period (Table 2), the modeling study by von der Heydt et al. (2011) [44] is one of the few to consider the effect of an open seaway. The mathematical modeling undertaken in that study is sophisticated and difficult to evaluate. However, it concludes that weak trade winds during the Pliocene Warm Period were unlikely, and hence a permanent El Niño would have been unrealistic. A more recent study by Lam et al. (2021) [79] that relies on microfossils posits a multi-stage history in the development of the Kuroshio Current off present-day Japan. During the Pliocene Warm Period, an early stage reflects warmer SSTs and sluggish movement that evolved though a strong temperature/salinity gradient. Only after the Pliocene Warm Period at $~ 2.9 \mathrm{Ma}$, the Kuroshio Current is said to approximate its modern-day configuration as a major western boundary current bringing moisture to high latitudes [79]. By implication, a slow-down in the western moving Pacific equatorial currents may have influenced a weaker Kuroshio Current at the same time.

With regard to paleoecology, the local effect of a throughgoing current passing across the Caribbean into the eastern Pacific is evident due to immigration by Atlantic and Caribbean based coral and bryozoan faunas into the Gulf of California on Mexico's western coast $[80,81]$. This outcome implies the Pliocene presence of a north-drifting counter current along the shores of Central America and probably a similar south-drifting current off the northwest coast of South America due to a pooled bulge in surface waters that formed as a spill-over effect. The mechanics of such a bulge were pointed out by Weaver (1990) [82] as a distinct likelihood during the early Pliocene, by analogy with the present day through-flow of equatorial currents from the Pacific to Indian oceans between Indonesia and New Guinea, 
that stimulates the north to south poleward drift of the warm Leeuwin Current along the west coast of Australia. That anomalous current supports the $260-\mathrm{km}$ long Ningaloo reef track off Western Australia in a position otherwise unsuited for coral growth.

The question is whether or not the Eastern Pacific Pool (EPP) of surface water may have been affected during the Pliocene due to reduced upwelling from the south moving California and north moving Humboldt currents, which in turn may have altered Walker Cell circulation in the atmosphere above the Pacific equator. The modeling by von der Heydt et al. (2011) [44] projects a western shift in the position of the cold tongue due to equatorial upwelling by up to $2000 \mathrm{~km}$, but does not consider the possible influence of counter flow against the California and Humboldt currents or the altered strength of the Kuroshio Current.

\section{Conclusions}

Pertinent to the Pliocene Warm Period, as generally defined between $\sim 4.5$ and 3.0 million years ago [16,17], this review combines and attempts to balance research results not usually treated in the same discussion. Namely, the two fields of study consulted are those based on temperature-sensitive planktonic foraminifera and other organics retrieved as fossil remains from deep-sea cores, contrasted against land-based studies of non-biological accumulations preserved as coastal boulder deposits (CBDs) and coastal outwash deposits (CODs). Where alternate sources of energy such as tsunamis or extra-terrestrial impacts of bolides can be eliminated, the CBDs reflect events of hurricane intensity more often responsible for erosion on rocky shorelines resulting in coarse conglomerate. The same storms bring heavy rain with landfall, which can lead to the development of extensive CODs. A secondary goal of this review is to examine similar CBDs from the end of the Pleistocene Epoch roughly 125,000 years ago (correlative with Substage Marine Isotope 5e) and the Holocene during the last 10,000 years. The following conclusions are drawn from this process.

- The latest findings from the extensive literature on the Pliocene Warm Period argue against permanent El Niño conditions not only in the Pliocene Pacific Ocean, but more broadly worldwide. However, even the strongest proponents of a normal Pliocene El Niño suggest that elevations of $\mathrm{CO}_{2}$ concentrations much higher than 400 ppm should induce a more persistent El Niño effect.

- Opposing studies tend to ignore the notion of a feed-back loop, whereby the steady increase in tropical disturbances of hurricane strength induce greater surface-water mixing and higher SSTs spreading beyond the equatorial zone and thereby more continuous El Niño conditions. In the opposite camp, studies that favor persistent El Niño conditions during the Pliocene Warm Period tend to ignore the notion that warming of SSTs in the equatorial Pacific may have been influenced by the open passageway between the North and South American continents irrespective of rising $\mathrm{CO}_{2}$ levels.

- $\quad$ Repetitive Pliocene CODs found throughout Mexico's Gulf of California required higher rainfall in that region than today in order to achieve thicknesses of several meters between natural breaks. In turn, their presence suggests more persistent El Niño conditions as a source of local rainfall. Evidence for intense Pliocene activity is less known in the Atlantic realm but does exist as for example in the Azores, although limited overall by the availability of Pliocene island deposits.

- The end of the Pleistocene Epoch and succeeding 10,000 years of the Holocene represent a much smaller time frame than the Pliocene Warm Period, but evidence for CBDs during those intervals is even more extensive. With regard to climate-change studies, however, care must be exercised to eliminate examples due to non-climate related influences such as earthquake-induced tsunamis.

Future research on the Pliocene Warm Period is certain to provide greater insight on an interval of time during which average global temperatures and sea level exceeded what we experience today. 
Funding: This research received no external funding.

Institutional Review Board Statement: Not Applicable.

Informed Consent Statement: Not Applicable.

Acknowledgments: The line drawings for this article were improved by B. Gudveig Baarli. Three anonymous readers contributed peer reviews with useful comments that led to the improvement of this contribution.

Conflicts of Interest: The author declares no conflict of interest.

\section{References}

1. UNESCO World Heritage List. Available online: https://whc.unesco.org/en/list/ (accessed on 29 October 2021).

2. Petit, J.-R.; Raynaud, D. Forty years of ice-core records of $\mathrm{CO}_{2}$. Nature 2020, 579, 505-506. [CrossRef] [PubMed]

3. Howe, J.P. This is nature; this is un-nature: Reading the Keeling curve. Environ. Hist. 2015, 20, 286-293. [CrossRef]

4. NOAA Research News. Available online: https://research.noaa.gov/article/ArtMID/587/ArticleID/2764 (accessed on 29 October 2021).

5. Cheng, L.; Abraham, J.; Zhu, J.; Trenbereth, K.E.; Fasullo, J.; Boyer, T.; Locarnini, R.; Zhang, B.; Yu, F.; Wan, L.; et al. Record-setting ocean warmth continued in 2019. Adv. Ocean Sci. 2020, 37, 137-142. [CrossRef]

6. Oliver, E.C.J.; Donat, M.G.; Burrows, M.T.; More, P.J.; Smale, D.A.; Alexander, L.V.; Benthuysen, J.A. Longer and more frequent marine heatwaves over the century. Nat. Commun. 2018, 9, 1324. [CrossRef] [PubMed]

7. Kossin, J.P.; Knapp, K.R.; Olander, T.L.; Velden, C.S. Global increase in major tropical cyclone exceedance probability over the past four decades. Proc. Natl. Acad. Sci. USA 2020, 117, 11975-11980. [CrossRef]

8. Wang, S.; Toumi, R. Recent migration of tropical cyclones toward coasts. Science 2021, 371, 514-517. [CrossRef]

9. Dumitru, O.; Austermann, J.; Pollyak, V.J.; Fornós, J.J.; Asmerom, Y.; Ginees, J.; Ginés, A.; Onac, B.P. Constraints on global mean sea level during Pliocene warmth. Nature 2019, 574, 233-236. [CrossRef] [PubMed]

10. Miller, K.G.; Browning, J.V.; Schmelz, W.J.; Kopp, R.E.; Mountain, G.S.; Wright, J.D. Cenozoic sea-level and cryospheric evolution from deep-sea geochemical and continental margin records. Sci. Adv. 2020, 6, eaaz1346. [CrossRef]

11. Rybczynski, N.; Gosse, J.C.; Harington, C.R.; Wogeliums, R.A.; Hidy, A.J.; Buckley, M. Mid-Pliocene warm-period deposits in the high Arctic yield insight into camel evolution. Nat. Commun. 2013, 4, 1-9. [CrossRef] [PubMed]

12. Budyko, M.I. The Earth's Climate: Past and Future; Academic Press: New York, NY, USA, 1982; 336p.

13. Zubakov, V.A.; Borzenkova, I.I. Pliocene palaeoclimates: Past climates as possible analogues of mid-twenty-first century climate. Palaeogeog. Palaeoclim. Palaeoecol. 1988, 65, 35-49. [CrossRef]

14. Mei, W.; Xie, S.-P. Intensification of landfalling typhoons over the northwest Pacific since the late 1970s. Nat. Geosci. 2016, 9, 753-757. [CrossRef]

15. You, Z.-J. Tropical cyclone-induced hazards caused by storm surges and large waves on the coast of China. Geosciences 2019, 9, 131. [CrossRef]

16. Wara, M.W.; Ravelo, A.C.; Delaney, M.L. Permanent El Niño-like conditions during the Pliocene Warm Period. Science 2005, 309, 758-761. [CrossRef] [PubMed]

17. Ravelo, A.C.; Dekens, P.S.; McCarthy, M. Evidence for El Niño-like conditions during the Pliocene. GSA Today 2006, 16, 4-11. [CrossRef]

18. Brierley, C.M.; Fedorov, A.V.; Honghui, L.; Herbert, T.D.; Lawrence, K.T.; LaRiviere, J.P. Greatly expanded tropical warm pool and weakened Hadley circulation in the early Pliocene. Science 2009, 323, 1714-1718. [CrossRef]

19. Molnar, P.; Cane, M. Early Pliocene (pre-Ice Age) El Niño-like global climate: Which El Niño? Geosphere 2007, 3, 337-365. [CrossRef]

20. White, S.M.; Ravelo, A.C. Dampened El Ninño in the early Pliocene warm period. Geophys. Res. Lett. 2020, 47, e2019GL085504. [CrossRef]

21. Emanuel, K.; Sundararajan, R.; Williams, J. Hurricanes and global warming: Results from downscaling IPCC AR4 simulations. Bull. Am. Meteorol. Soc. 2008, 89, 347-368. [CrossRef]

22. May, S.M.; Engel, M.; Brill, D.; Squire, P.; Scheffers, A.; Kelletat, D. Coastal hazards from tropical cyclones and extratropical winter storms based on Holocene storm chronologies. In: Finkl, C.W. (ed.) Coastal Hazards. Coast. Res. Libr. 2013, 6, 557-585.

23. Johnson, M.E.; Ledesma-Vázquez, J.; Guardado-Grance, R. Coastal geomorphology of a Holocene Hurricane Deposit on a Pleistocene Marine Terrace from Isla Carmen (Baja California Sur, Mexico). J. Mar. Sci. Eng. 2018, 6, 108. [CrossRef]

24. Johnson, M.E.; Guardado-France, R.; Johnson, E.M.; Ledesma-Vázquez, J. Geomorphology of a Holocene Hurricane deposit eroded from rhyolite sea cliffs on Ensenada Almeja (Baja California Sur, Mexico). J. Mar. Sci. Eng. 2019, 7, 193. [CrossRef]

25. Johnson, M.E.; Johnson, E.M.; Guardado-France, R.; Ledesma-Vázquews, J. Holocene hurricane deposits eroded as coastal barriers from andesite sea cliffs at Puerto Escondido (Baja California Sur, Mexico). J. Mar. Sci. Eng. 2020, 8, 75. [CrossRef]

26. Guardada-France, R.; Johnson, M.E.; Ledesma-Vázquez, J.; Santa Rosa-del Rio, M.A.; Herrera-Gutiérrez, Á. Multiphase storm deposits eroded from andesite sea cliffs on Isla San Luis Gonzaga (Northern Gulf of California Mexico). J. Mar. Sci. Eng. 2020, 8,525 . [CrossRef] 
27. Callahan, G.; Johnson, M.E.; Guardado-Grance, R.; Kedesna-Vázquez, J. Upper Pleistocene and Holocene storm deposits the granodiorite coast on Isla Sn Diego (Baja California Sur, Mexico). J. Mar. Sci. Eng. 2021, 9, 555. [CrossRef]

28. Ávila, S.P.; Johnson, M.E.; Rebelo, A.C.; Baptista, L.; Melo, C.S. Comparison of modern and Pleistocene (MIS 5e) coastal Boulder deposits from Santa Maria Island (Azores Archipelago, NE Atlantic Ocean). J. Mar. Sci. Eng. 2020, 9, 386. [CrossRef]

29. Galindo, I.; Johnson, M.E.; Martín-González, E.; Romero, C.; Vegas, J.; Melo, C.S.; Ávila, S.P.; Sánchez, N. Late Pleistocene boulder slumps eroded from a basalt shoreline at El Confital Beach on Gran Canaria (Canary Islands, Spain). J. Mar. Sci. Eng. 2020, 9, 138. [CrossRef]

30. Johnson, M.E. Holocene boulder beach eroded from chromite and dunite sea cliffs at Støpet on Leka Island (Northern Norway). J. Mar. Sci. Eng. 2020, 8, 644. [CrossRef]

31. Morton, R.A.; Richmond, B.M.; Jaffe, B.E.; Gelfenbaum, G. Coarse-clast ridge complexes of the Caribbean: A preliminary basis for distinguishing tsunami and storm-wave origins. J. Sed. Res. 2008, 78, 624-637. [CrossRef]

32. Lorang, M.S. A wave-competence approach to distinguish between boulder and megaclast deposits due to storm waves versus tsunamis. Mar. Geol. 2011, 283, 90-97. [CrossRef]

33. Ball, M.M.; Shinn, E.A.; Stockman, K.W. The geologic effects of Hurricane Donna in South Florida. J. Geol. 1967, 75, 583-597. [CrossRef]

34. Paris, R.; Fournier, J.; Poizot, E.; Etienne, S.; Morin, J.; Lavigne, F.; Wassmer, P. Boulder and fine sediment transport and deposition by the 2004 tsunami in Lhok Nga (western Banda Acheh, Indonesia): A coupled offshore-onshore model. Mar. Geol. 2010, 268, 43-54. [CrossRef]

35. Dowsett, H.J.; Robinson, M.M. Mid-Pliocene equatorial Pacific sea surface temperature reconstruction: A multi-proxy perspective. Philos. Trans. R. Soc. 2009, 367, 109-125. [CrossRef] [PubMed]

36. Haywood, A.M.; Valdes, P.J.; Peck, V.L. A permanent El Niño during the Pliocene? Paleoceanography 2007, 22, PA1213. [CrossRef]

37. Dowsett, H.J.; Chandler, M.A.; Robinson, M.M. Surface temperatures of the Mid-Pliocene North Atlantic Ocean: Implications for future climate. Philos. Trans. R. Soc. A 2009, 367, 69-84. [CrossRef] [PubMed]

38. Fedorov, A.V.; Brierly, C.M.; Emanuel, K. Tropical cyclones and permanent El Niño in the early Pliocene epoch. Nature 2010, 463, 1066-1071. [CrossRef] [PubMed]

39. Nott, J. Waves, coastal bolder deposits and the importance of pre-transport setting. Earth Planet. Sci. Lett. 2003, 210, 269-276. [CrossRef]

40. Nandasena, N.A.K.; Paris, R.; Tanaka, N. Reassessment of hydrodynamic equations: Minimum flow velocity to initiate boulder transport by high energy events (storms, tsunamis). Mar. Geol. 2011, 281, 70-84. [CrossRef]

41. Pepe, F.; Corradino, M.; Parrino, N.; Besio, G.; Presti, V.L.; Renda, P.; Calcagnile, L.; Quarta, G.; Sulli, A.; Antonioli, F. Boulder coastal deposits at Favignana Island rocky coast (Sicily, Italy): Litho-structural and hydrodynamic control. Geomorphology 2018, 303, 191-209. [CrossRef]

42. Dekens, P.S.; Ravelo, A.C.; McCarthy, M.D. Warm upwelling regions in the Pliocene warm period. Paleoceanography 2007, 22, PA3211. [CrossRef]

43. Schepper, S.D.; Greoeneveld, J.; Naafs, B.D.A.; Van Renterghem, C.; Hennissen, J.; Head, M.J.; Louwye, S.; Fabian, K. Northern Hemisphere glaciation during the Globally Warm early late Pliocene. PLoS ONE 2013, 8, e81508. [CrossRef]

44. Von der Heydt, A.S.; Nnafie, A.; Dijkstra, H.A. Cold tongue/Warm pool and ENSO dynamics in the Pliocene. Clim. Past 2011, 7, 903-915. [CrossRef]

45. O’Brien, C.L.; Foster, G.L.; Martínez-Boti, M.A.; Abell, R.; Rae, J.W.B.; Pancost, R.D. High sea surface temperatures in tropical warm pools during the Pliocene. Nat. Geosci. 2014, 7, 606-611. [CrossRef]

46. Haywood, A.M.; Dowsett, H.J.; Dolan, A.M. Integrating geological archives and climate models for the mid-Pliocene warm period. Nat. Commun. 2016, 7, 10646. [CrossRef] [PubMed]

47. Tierney, J.E.; Haywood, A.M.; Fend, R.; Bhattacharya, T.; Otto-Bliesner, B.L. Pliocene warmth consistent with greenhouse gas forcing. Geophys. Res. Lett. 2019, 46, 9136-9144. [CrossRef]

48. Ruban, D.A. Coastal bolder deposits of the Neogene world: A synopsis. J. Mar. Sci. Eng. 2019, 7, 446. [CrossRef]

49. Ruban, D.A. Finding coastal megaclast deposits: A virtual perspective. J. Mar. Sci. Eng. 2020, 8, 164. [CrossRef]

50. Yao, Q.; Liu, K.-b.; Wu, Y.; Aragón-Moreno, A.A.; Rodriques, E.; Cohen, M.; de Souza, A.V.; Farfán, L.M.; Antinao, J.L. A multiproxy record of hurricanes, tsunami, and post-disturbance ecosystem changes from coastal southern Baja California. Sci. Total Environ. 2021, 796, 149011. [CrossRef]

51. Johnson, M.E.; Backus, D.H.; Ledesma-Vázquez, J. Growth of the Ballena fan delta on the Gulf of California (Mexico) at the close of the Pliocene Warm Period. Facies 2017, 63, 14. [CrossRef]

52. Johnson, M.E.; Ledesma-Vázquez, J.; Backus, D.H. Tectonic decapitation of a Pliocene mega-delta on Isla del Carmen in the Gulf of California (Mexico): And a river ran through it. J. Geol. 2016, 124, 55-74. [CrossRef]

53. Emhoff, K.F.; Johnson, M.E.; Backus, D.H.; Ledesma-Vázquez, J. Pliocene stratigraphy at Paredones Blancos: Significance of a massive crushed-rhodolith deposit on Isla Cerralvo, Baja California Sur (Mexico). J. Coast. Res. 2012, 28, 234-243. [CrossRef]

54. Johnson, M.E.; Ledesma-Vázquez, J. Biological zonation on a rocky-shore boulder deposit: Upper Pleistocene Bahía San Antonio (Baja California Sur, Mexico). Palaios 1999, 14, 569-584. [CrossRef]

55. Ledesma-Vázquez, J.; Johnson, M.E.; Backus, D.H.; Mirabal-Davial, C. Coastal evolution from transgressive barrier deposit to marine terrace on Isla Coronados, Baja California Sur, Mexico. Cienc. Mar. 2007, 33, 335-351. [CrossRef] 
56. Tierney, P.W.; Johnson, M.E. Stabilization role of crustose coralline algae during Late Pleistocene reef development on Isla Cerralvo, Baja California Sur (Mexico). J. Coast. Res. 2012, 28, 244-254. [CrossRef]

57. Kozlowski, J.A.; Johnson, M.E.; Ledesma-Vázquez, J.; Birgel, D.; Peckmann, J.; Schleper, C. Microbial diversity of a closed salt lagoon in the Puertecitos area, Upper Gulf of California. Cienc. Mar. 2018, 44, 71-90. [CrossRef]

58. Johnson, M.E.; Ledesma-Vázquez, J.; Backus, D.H.; González, M.R. Lagoon microbialites on Isla Angel de la Guarda and associated peninsular shores, Gulf of California (Mexico). Sed. Geol. 2012, 263-264, 76-84. [CrossRef]

59. Backus, D.H.; Johnson, M.E.; Riosmena-Rodríguez, R. Distribution, sediment source, and coastal erosion of fan-delta systems on Isla Cerralvo (Lower Gulf of California Mexico). J. Coast. Res. 2012, 28, 210-224. [CrossRef]

60. Johnson, M.E.; Uchman, A.; Costa, P.J.M.; Ramalho, R.S.; Ávila, S.P. Intense hurricane transports sand onshore: Example from the Pliocene Malbusca secion on Santa Maria Island (Azores Portugal). Mar. Geol. 2017, 385, 244-249. [CrossRef]

61. Hearty, P.J.; Tormey, B.R. Sea-level change and superstorms; geologic evidence from the last interglacial (MIS 5e) in the Bahamas and Bermuda offers ominous prospects for a warming Earth. Mar. Geol. 2017, 390, 347-365. [CrossRef]

62. Rovere, A.; Casella, E.; Harris, D.L.; Lorscheid, T.; Nandesena, N.A.K.; Dyer, B.; Sandstrom, M.R.; Stocchi, P.; D'Andrea, W.J.; Raymo, M.E. Giant boulders and last interglacial storm intensity in the North Atlantic. Proc. Natl. Acad. Sci. USA 2017, 114, 12144-12149. [CrossRef]

63. Cox, R.; Ardhuin, F.; Dias, F.; Autret, R.; Beisiegel, N.; Earlie, C.S.; Herterich, J.G.; Kennedy, A.; Paris, R.; Raby, A.; et al. Systematic review shows that work done by storm waves can be misinterpreted as tsunami- because commonly used hydrodynamic equations are flawed. Front. Mar. Sci. 2020, 7, 4. [CrossRef]

64. Hall, A.M.; Hansom, J.D.; Williams, D.M.; Jarvis, J. Distribution geomophology and lithofacies of cliff-top storm deposits: Examples from the high-energy coasts of Scotland and Ireland. Mar. Geol. 2006, 232, 131-155. [CrossRef]

65. Cox, R.; Zentner, D.B.; Kirchner, B.J.; Cook, M.S. Boulder ridges on the Aran Islands (Ireland): Recent movements caused by storm waves, not tsunamis. J. Geol. 2012, 120, 249-272. [CrossRef]

66. Erdmann, W.; Scheffers, A.M.; Kelletat, D.H. Holocene coastal sedimentation in a rocky environment: Geomophological evidence from the Aran Islands and Galway Bay (Western Ireland). J. Coast. Res. 2018, 34, 772-792. [CrossRef]

67. Etienne, S.; Paris, R. Boulder accumulations related to storms on the south coast of the Reykjanes peninsula (Iceland). Geomorphology 2010, 114, 55-70. [CrossRef]

68. Super Typhoon Haiyan. Available online: https:/ / en.wikipedia.org/wiki/Typhoon_Haiyan (accessed on 29 October 2021).

69. Kennedy, A.B.; Mori, N.; Zhang, Y.; Yasuda, T.; Chen, S.E.; Tajima, Y.; Pecor, W.; Toride, K. Observations and modeling of coastal boulder transport and loading during Super Typhoon Haiyan. Coast. Eng. J. 2016, 58, 164004. [CrossRef]

70. Kennedy, A.B.; Mori, N.; Yasuda, T.; Shimozona, T.; Tomiczek, T.; Donahue, A.; Shimura, T.; Imai, Y. Extreme block and boulder transport along a cliffed coastline (Calicoan island Philippines) during Super Typhoon Haian. Mar. Geol. 2017, 383, 65-77. [CrossRef]

71. Mori, N.; Kato, M.; Kim, S.; Mase, H.; Shibutani, Y.; Takemi, T.; Tsuboki, K.; Yasuda, T. Local amplification of storm surge by Super Typhoon Haiyan in Leyte Gulf. Geophys. Res. Lett. 2014, 41, 5106-5113. [CrossRef]

72. Herterich, J.G.; Cox, R.; Dias, F. How does wave impact generate large boulders? Modelling hydraulic fracture of cliffs and shore platforms. Mar. Geol. 2018, 399, 34-46. [CrossRef]

73. Pérez-Torrado, F.J.; Paris, R.; Cabrera, M.C.; Schneider, J.L.; Wassmer, P.; Carracedo, J.C.; Santana, F. Tsunami deposits related to flank collapse in oceanic volcanoes: The Agaete Valley evidence, Gran Canaria, Canary Islands. Mar. Geol. 2006, 227, 135-149. [CrossRef]

74. Ramalho, R.S.; Winckler, G.; Madeira, J.; Helffrich, G.R.; Hipólito, A.; Quartau, R.; Adena, K.; Schaefer, J.M. Hazard potential of volcanic flank collapses raised by new megatsunami evidence. Sci. Adv. 2015, 1, e1500456. [CrossRef]

75. Biolchi, S.; Furlani, S.; Antonioli, F.; Baldassini, N.; Causon Deguara, J.; Devoto, S.; Di Stefano, A.; Evans, J.; Gambin, T.; Gauci, R.; et al. Boulder accumulations related to extreme wave events on the eastern coast of Malta. Nat. Hazards Earth Syst. Sci. 2016, 16, 737-756. [CrossRef]

76. Hartley, A.; Howell, J.; Mather, A.E.; Chong, G. 2001. A possible Plio-Pleistocene tsunami deposit, Hornitos, northern Chile. Rev. Geol. Chile 2001, 28, 117-125. [CrossRef]

77. Spliske, M.; Bahlburg, H.; Weiss, R. Pliocene mass failure deposits mistaken as submarine tsunami backwash sediments-An example from Hornitos, northern Chile. Sediment. Geol. 2014, 305, 69-82. [CrossRef]

78. Coates, A.G.; Jackson, J.B.; Collins, L.S.; Cronin, T.M.; Dowsett, H.J.; Bybell, L.M.; Jung, P.; Obando, J.A. Closure of the Isthmus of Panama: The near-shore marine record of Costa Rica and western Panama. Geol. Soc. Am. Bull. 1992, 104, 814-828. [CrossRef]

79. Lam, A.R.; MacLeod, K.G.; Schilling, S.H.; Leckie, R.M.; Fraass, A.J.; Patterson, M.O.; Venti, N.L. Pliocene to earlies Pleistocene (5-2.5 Ma) reconstruction of the Kuroshio Current extension reveals a dynamic current. Paleoceanog. Paleoclimat. 2021, 36, e2021PA004318. [CrossRef]

80. Foster, A.B. Environmental variation in a fossil scleractinian coral. Lethaia 1979, 121, 245-264. [CrossRef]

81. Cuffey, R.J.; Johnson, M.E. Bryozoan nodules build around andesite clasts from the upper Pliocene of Baja California: Paleoecological implications and closure of the Panama Isthmus. Geol. Soc. Am. Spec. Pap. 1997, 318, 111-117.

82. Weaver, A.J. Ocean currents and climate. Nature 1990, 347, 432. [CrossRef] 